\title{
Geotechnical risk management for open pit mine closure: a sub-arctic and semi-arid case study
}

\author{
PJH de Graaf The De Beers Group of Companies, Anglo American, South Africa \\ M Desjardins De Beers Canada Inc., Canada \\ P Tsheko Anglo American Metallurgical Coal, South Africa
}

\begin{abstract} has poor wall performance associated many with mudstone and country rock breccia instabilities. the closure exclusion zone). This involved:

1) Pit break back-analysis using

i) industry guidelines;

ii) an empirical approach based on historical slope instabilities; and

iii) stability analysis using predicted post-closure phreatic surfaces.
\end{abstract}

De Beers is currently developing closure plans for two open pit mines. At first glance they appear quite similar; both are relatively remote, have operated for 10 years, have similar pit dimensions (250-300 m deep and $1.5 \mathrm{~km}$ wide) and have Palaeozoic sedimentary host lithologies with weak upper units overlying more competent lower materials. However, Victor Mine in the sub-Arctic Canada, is one of De Beers wettest mines (dewatering volume of $75,000 \mathrm{~m}^{3} / \mathrm{d}$ ) and is hosted predominantly in good quality limestone with excellent final wall performance. While Voorspoed Mine, in semi-arid Southern Africa required virtually no dewatering,

Victor Mine is expected to achieve stable pit lake in less than 10 years (and less than 2 years with supplementation from a nearby river), while Voorspoed will take over 100 years to reach ultimate pit lake level (due to low groundwater inflows, high evaporation and limited opportunity for flow supplementation).

This paper describes a process to determine closure stability design acceptance criteria (DAC) and characterise the zone of long-term surface disturbance surrounding the pit (i.e.: potentially unstable pit edge zone to define

2) Estimates of erosion potential.

These results along with the well documented historical slope performance provided the basis for detailed Geotechnical Risk Assessments which addressed two periods.

- Active closure with personnel undertaking rehabilitation activities in and surrounding the pits, and

- Long-term closure, personnel and equipment not permitted within the long-term break back zone.

Risk-based monitoring plans were developed along with Trigger Action Response Plans (TARPs) to ensure that closure of the pit proceeds safely and efficiently while satisfying the regulatory requirements.

Keywords: design acceptance criteria, Geotechnical risk management, pit slope closure, safe setback distance

\section{Introduction}

All mines eventually need to be closed to the satisfaction of internal and external stakeholders. This paper focuses on the geotechnical aspects relating to open pit stability and closure; slope stability of other facilities such as coarse and fine residue dumps and waste dumps are not considered (but detailed rehabilitation and management plans are in place for these facilities). 
Slope deformation resulting in significant surface strain (damaging existing infrastructure), and/or catastrophic collapse (potentially impacting mine personnel or the public) are the principal geotechnical risks associated with open pit closure. Although these consequences are potentially significant, they are however very unlikely outcomes, particularly sudden catastrophic collapse - especially with appropriate slope designs, monitoring systems and TARPs in place. Arguably the most significant risk is reputational; should the closure conditions not be fully achieved external stakeholders, community and importantly regulators could lose confidence in the plan and/or impose additional constraints on the current closure plan or on future closure plans in that jurisdiction.

Establishing safe setback distances to define the limits for public access is the preferred approach to minimise inadvertent public access areas which may be susceptible to slope collapse. These are typically delineated by bunds and signage, sometimes in conjunction with high fences. Careful consideration is required, to balance the objectives of maximising the land area to be reinstated to its prior utilisation (potentially including public access) by minimising the setback distance and exclusion zone, and the requirement to ensure that the safety imperatives and other stability commitments are achieved. Anticipated impacts can be managed, however unexpected collapse and increased area of impact is a significant problem with potential loss of life, legal action, reputational damage and loss of trust from the public and regulators.

Understanding and predicting credible modes of instability and how these may manifest in the future is required to manage these risks. This is not a trivial exercise, as not only do the usual geotechnical design input parameter uncertainties need to be managed, but also the time dependency of predicting stability 100 or even $\mathbf{2 0 0}$ years from now. That said, typically at the end of mining we know the most about the input models and parameters, as we have observed and refined these through calibration of performance and/or back-analysis of failures.

This challenge is not unique, mining-induced subsidence has been recognised since the start of mining and is first documented in Agricola's De Re Metallica (Agricola 1556). Several underground mining situations have similar requirements to define and predict future stability and zone of surface influence. Such as progressive hanging wall caving by Hoek (1974) and Brown \& Ferguson (1979), crown pillar stability by Dr. Carter and coworkers (Carter 1992; Carter \& Miller 1995; Carter 2014), and many authors addressing various aspects of caving-induced subsidence (Laubsher 2000; Flores \& Karzulovic 2002; van As et al. 2003; Sainsbury et al. 2018), and Sharrock et al. (2016) caving and subsidence, and coal mining subsidence by National Coal Board (1975), Salamon (1990) and Suchowerska Iwanec et al. 2015 and others. Figure 1(a) illustrates one of Flores \& Karzulovic many scenarios for predicting zone of influence in relation to excavation depth, and Figure 1(b) crest stability zones for Brown and Ferguson's idealised progressive hanging wall failure model.

Several approaches are available for assisting in defining the extent and area of possible impact:

- Industry rules of thumb or regulatory guidance notes.

- Empirical approaches based on historical slope instabilities and precedent break back angles.

- Limit equilibrium (LE) or finite element (FE) stability analyses using predicted post-closure conditions (e.g.: phreatic surfaces and pit lake levels at defined time periods).

Carter (2014) discusses similar methods for predicting the extent and area of influence for crown pillar collapse, and has sound advice that no single method should be considered as providing absolute magnitudes of ground disturbance, but should only be used as diagnostic indicator methods for establishing potential breakback extent outside the excavation footprint. Geological and pore pressure controls on potential failure are key, followed by slope geometry. At closure, final slope geometry is well understood. Generally shallow pits in strong rock masses or with sub-vertical structures the potential for possible breakback and surface impact is usually relatively narrow, whereas for deep pits in weak rock masses and with inclined geological structures with string anisotropy the potential surface impact could be much wider.

The following sections present details of the Victor and Voorspoed mines; and the closure criteria and outcomes. Table 1 summarises the key elements of the life-of-mine designs and performance. 


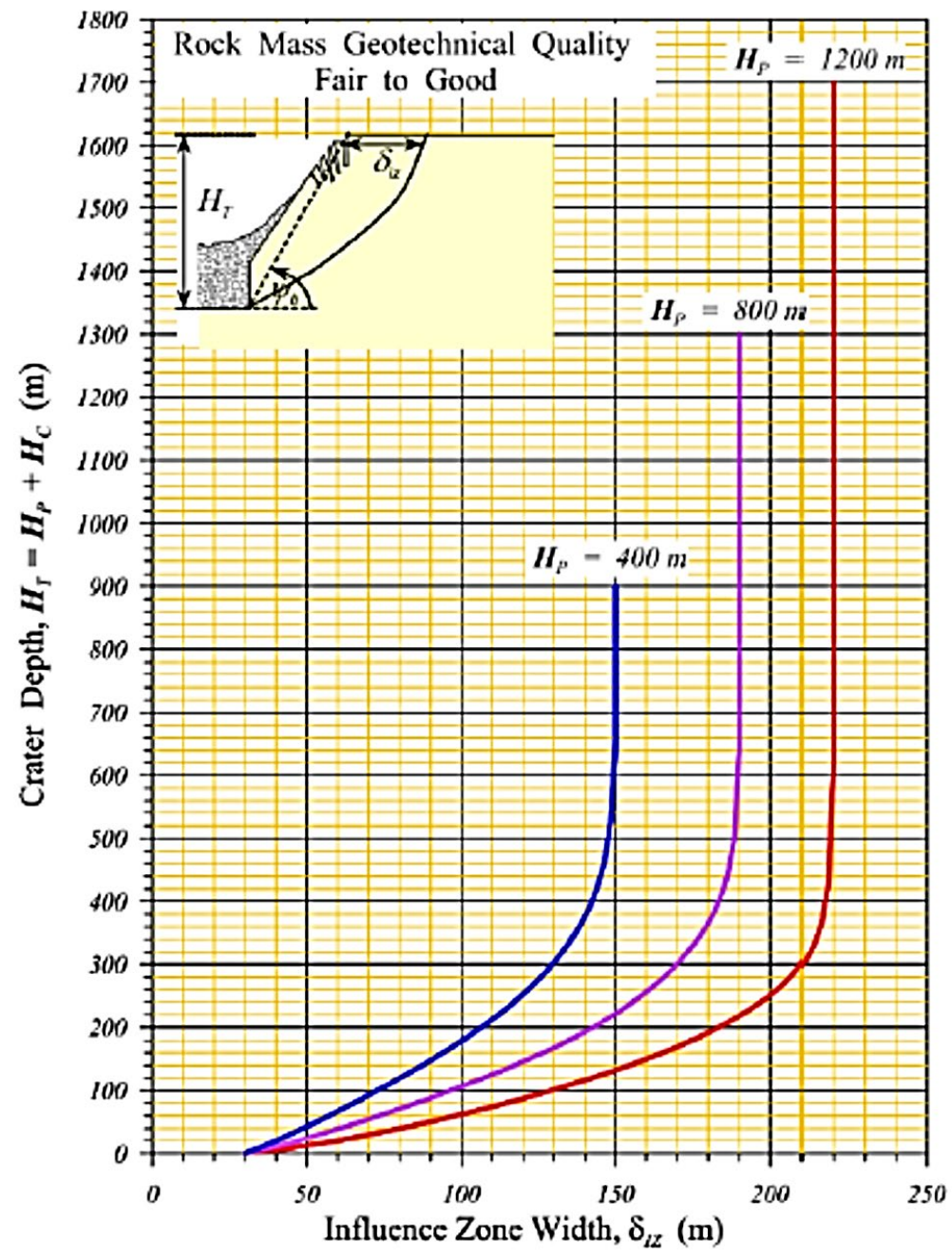

(a)

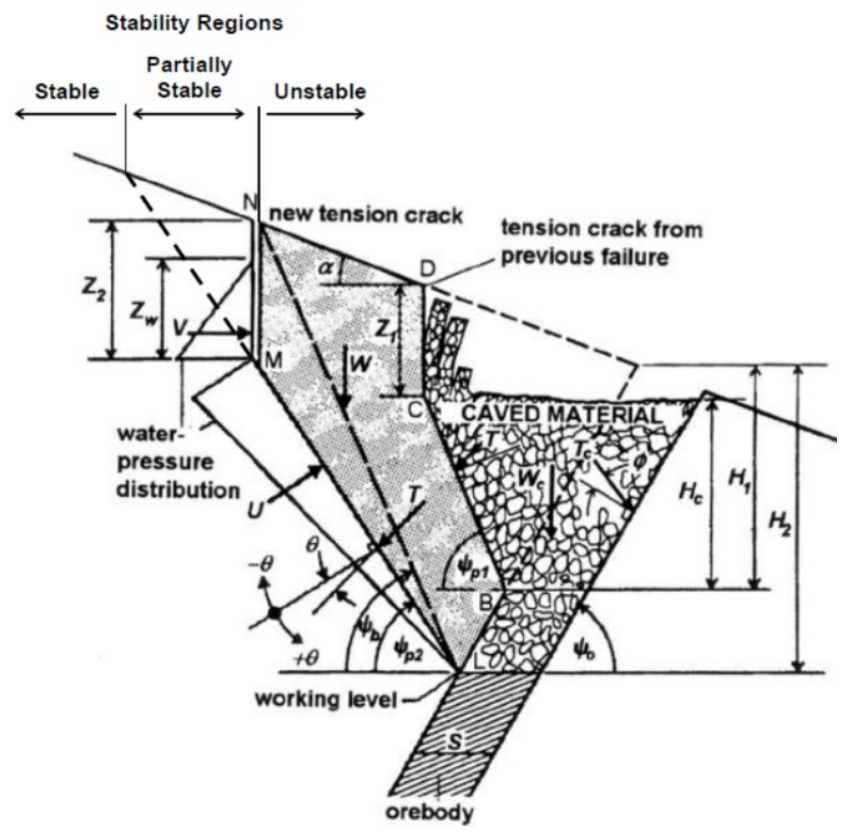

(b)

Figure 1 (a) Estimated crest zone of influence for pit and underground mining, after Flores \& Karzulovic (2002); (b) Progressive hanging wall instability model, after Brown \& Ferguson (1979) 
Table $1 \quad$ Life-of-mine design summary statistics

\begin{tabular}{|c|c|c|c|c|}
\hline & & & Victor Mine & Voorspoed Mine \\
\hline \multicolumn{3}{|c|}{ Mine life (years) } & 11 & 10 \\
\hline \multicolumn{3}{|c|}{ Total material moved $(\mathrm{t})$} & $88 \mathrm{M}$ & $119 \mathrm{M}$ \\
\hline \multicolumn{3}{|c|}{ Ore mined $(t)$} & $31.3 \mathrm{M}$ & $29.5 \mathrm{M}$ \\
\hline \multicolumn{3}{|c|}{ Carats recovered } & $8.16 \mathrm{M}$ & $6.4 \mathrm{M}$ \\
\hline \multicolumn{3}{|c|}{ Depth (m) } & 290 & 250 \\
\hline \multicolumn{3}{|c|}{ Width (m) } & 1,000 & 1,200 \\
\hline \multicolumn{3}{|c|}{ Dewatering ( $\mathrm{m}^{3} /$ day) } & $75,000-90,000$ & 3,750 \\
\hline \multicolumn{3}{|l|}{$\mathrm{BFA}\left({ }^{\circ}\right)$} & \multicolumn{2}{|c|}{ Typically $90^{\circ}$} \\
\hline \multirow{4}{*}{$\begin{array}{l}\text { IRA }\left({ }^{\circ}\right) \\
\text { and } \\
\text { Bench } \\
\text { height }\end{array}$} & & $\begin{array}{l}\text { Upper } \\
\text { sequence }\end{array}$ & $14^{\circ}$ (Clay) $10 \mathrm{~m}$ & $38^{\circ}$ (VO - Mudstone) BH $12 \mathrm{~m}$ \\
\hline & Sedimentary & Mid slope & $61^{\circ}$ (Limestone) $20 \mathrm{~m}$ & $\begin{array}{l}31^{\circ} \text { (VRM Fine Mudstone and } \\
\text { VRSSC_Upper - Shale) } 12 \mathrm{~m}\end{array}$ \\
\hline & & $\begin{array}{l}\text { Lower } \\
\text { slope }\end{array}$ & $50^{\circ}$ (Shale) $15 \mathrm{~m}$ & $\begin{array}{l}65^{\circ} \text { (VRSSC_Lower - } \\
\text { Conglomerates) } 24 \mathrm{~m}\end{array}$ \\
\hline & Igneous intru & & $63^{\circ}$ (Kimberlite) $20 \mathrm{~m}$ & $69^{\circ}$ (Kimberlite/Basalt) $24 \mathrm{~m}$ \\
\hline \multicolumn{3}{|l|}{ OSA $\left(^{\circ}\right)$} & $\sim 50^{\circ}$ & $\sim 41^{\circ}$ \\
\hline
\end{tabular}

\section{Victor Mine: sub-arctic case history}

\subsection{Location and climate}

Victor Mine is in the St James Bay Lowlands of Northern Ontario, $90 \mathrm{~km}$ west of the town of Attawapiskat (as shown in Figure 2). It is Ontario's first diamond mine and the second of three in Canada for De Beers. It is a remote fly-in/fly-out operation, a winter 'ice' road is available for 4-6 weeks to bring supplies and equipment to site.

Several kimberlite pipes have been discovered in the area since 1987, however only three pipes are mined at the Victor operation. First ore was mined in 2008 and last ore in March 2019.

Victor Mine has a sub-arctic climate, this climate has some of the most extreme seasonal temperature variations found on the planet; with long, very cold winters, and short, cool to mild summers. Winter temperatures can drop to below $-40^{\circ} \mathrm{C}$ and may exceed $30^{\circ} \mathrm{C}$ in summer. With average temperatures below freezing for about half the year the subsoil freezes solidly to depths of several meters. Comparative climate graphs are shown in Figure 3 for Victor and Voorspoed Mines. Interestingly both mines have similar total annual precipitation (450-550 $\mathrm{mm}$ ). Permafrost prevails under most areas not near the southern boundary of this climate zone, where summer warmth is insufficient to thaw more than the surface. Victor It is situated near the tree line and is sufficiently south for only discontinuous permafrost to occur. 


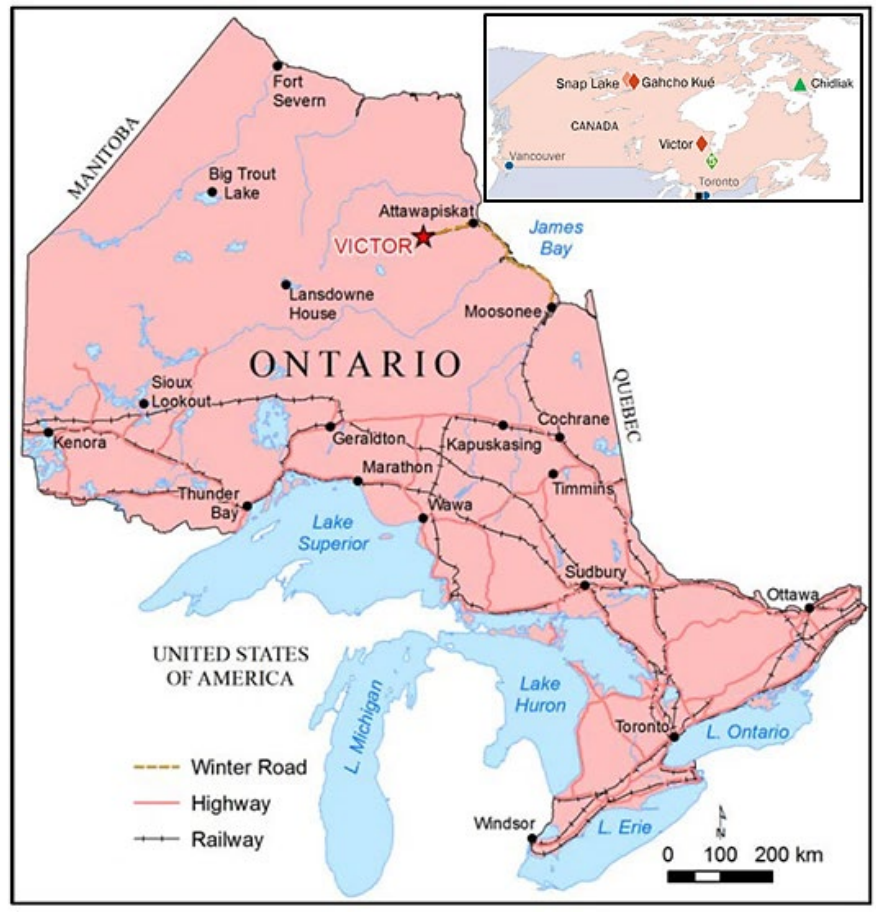

Figure 2 Victor Mine locality map
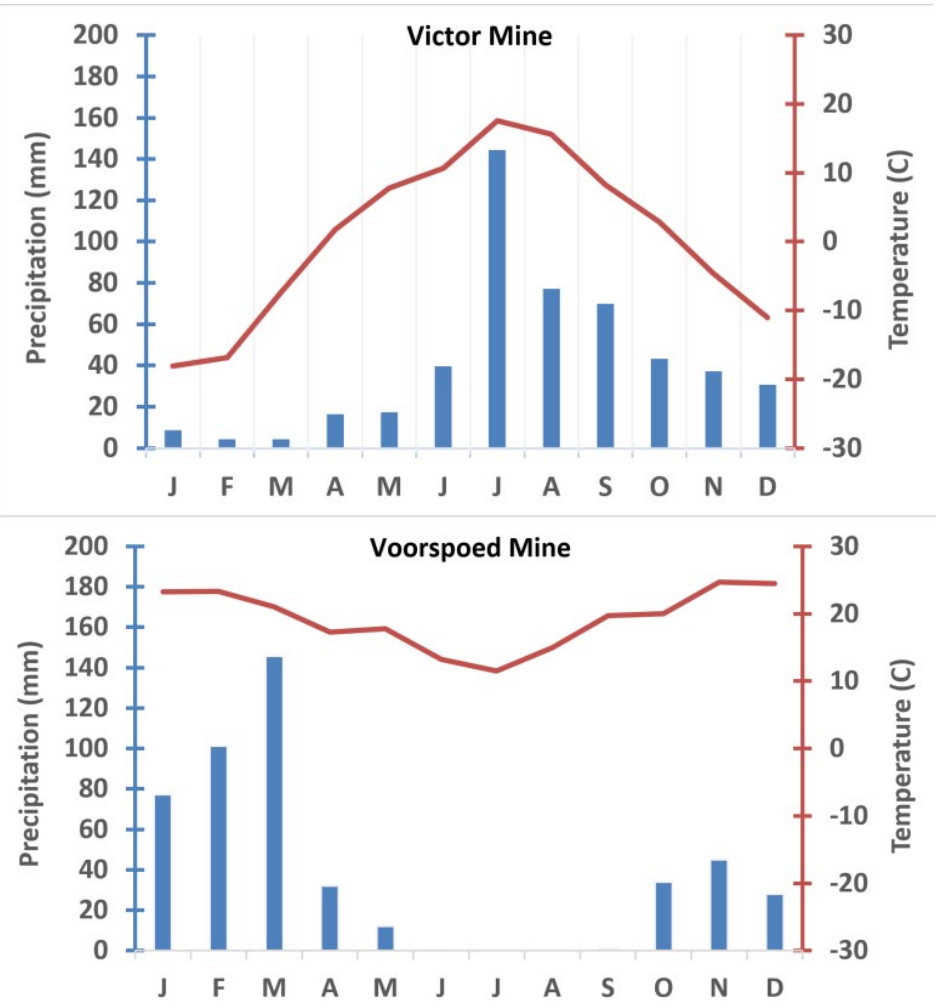

Figure 3 Comparison climate graphs for Victor and Voorspoed Mines 


\subsection{Geological setting}

The stratigraphy and lithology model is relatively simple, comprising three kimberlite pipes intruded into flatlying sedimentary sequence of Silurian limestone (105 m thick) overlying Ordovician mudstones and sandstones (135 $\mathrm{m}$ thick), which uncomfortably overlie Precambrian granitic basement. The bedrock sequence is in turn overlain by $30 \mathrm{~m}$ of lacustrine clay overburden. The upper portion of the limestone (about $50 \mathrm{~m}$ ) is weathered and has increased jointing, iron staining, and some enhanced karst development (Rougier et al. 2015). The pipes consist of multiple intrusions and various kimberlite facies, and are surrounded by an alteration zone in the limestone. Figure 4 illustrates the pit geology map showing geotechnical domains.

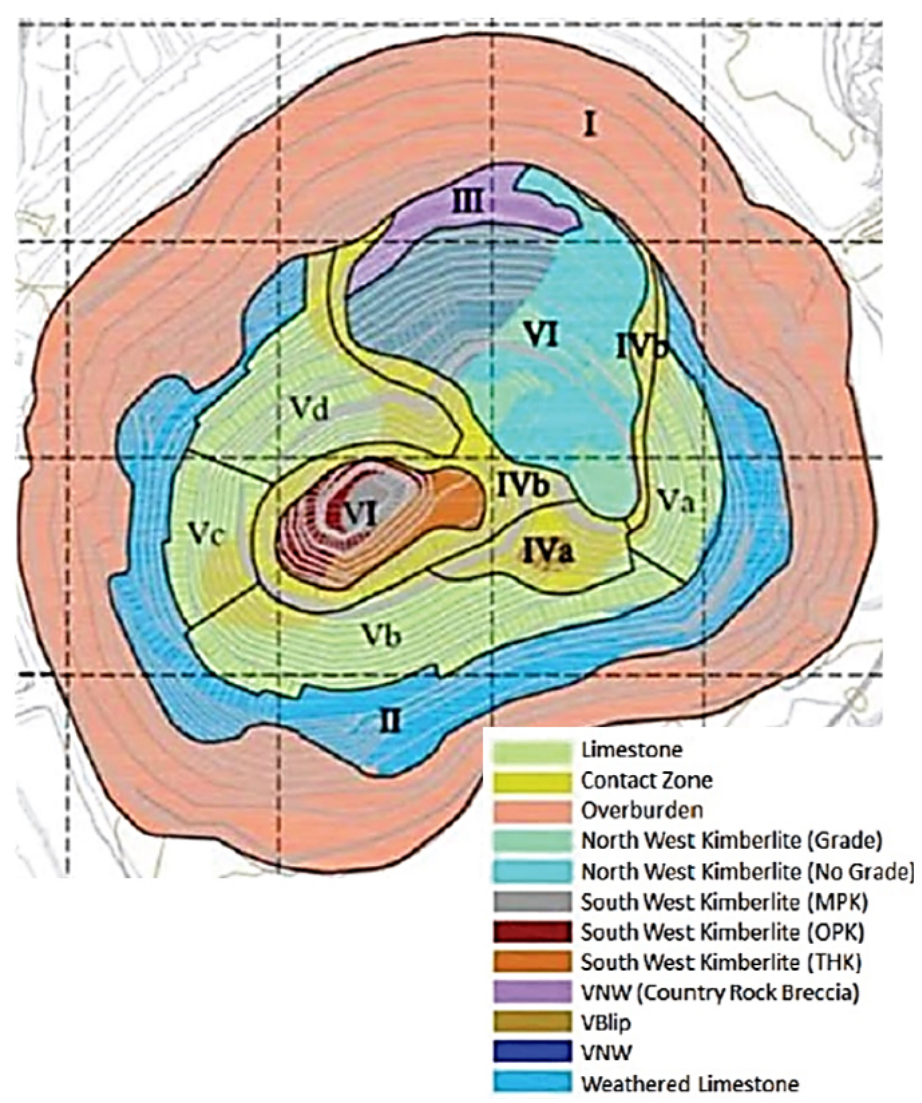

\begin{tabular}{|c|c|c|c|c|c|c|}
\hline $\begin{array}{c}\text { Geotechnical } \\
\text { Domain }\end{array}$ & $\begin{array}{c}\text { Domain } \\
\text { Description }\end{array}$ & $\begin{array}{c}\text { Batter } \\
\text { Angle (") }\end{array}$ & $\begin{array}{l}\text { Bench } \\
\text { Height } \\
\text { (m) }\end{array}$ & $\begin{array}{l}\text { Bench } \\
\text { Width } \\
\text { (m) }\end{array}$ & $\begin{array}{l}\text { IRA } \\
\text { (") }\end{array}$ & \begin{tabular}{|l} 
Maximum \\
Stack \\
Height (m)
\end{tabular} \\
\hline 1 & $\begin{array}{l}\text { Overburden } \\
\text { (Clay) }\end{array}$ & - & $10-20$ & $\cdot$ & $\begin{array}{c}4: 1(\mathrm{H}: \mathrm{V}) \\
\text { to } \\
5: 1(\mathrm{H}: \mathrm{V})\end{array}$ & - \\
\hline " & $\begin{array}{l}\text { Weathered } \\
\text { Limestone }\end{array}$ & 70 & 10 & 6.5 & 45 & 100 \\
\hline III & $\begin{array}{c}\text { Country Rock } \\
\text { Brecdia }\end{array}$ & 45 & 5 & 5.0 & 27 & 100 \\
\hline \multirow{6}{*}{ IV } & \multirow{2}{*}{$\begin{array}{l}\text { IV(a) - Contact } \\
\text { Zone - Blip } \\
\text { Alteration Halo }\end{array}$} & 70 & 10 & 6.5 & 45 & 60 \\
\hline & & 70 & 15 & 9.5 & 45 & 60 \\
\hline & \multirow{2}{*}{$\begin{array}{l}\text { IV(b)- Contact } \\
\text { Zone-Other } \\
\text { Limestone/ } \\
\text { Kimberlite }\end{array}$} & 70 & 10 & 6.5 & 45 & 60 \\
\hline & & 70 & 15 & 9.5 & 45 & 60 \\
\hline & \multirow{2}{*}{$\begin{array}{c}\text { IV(b) - Contact } \\
\text { Zone - Below } \\
230 \mathrm{~L}\end{array}$} & 70 & 10 & 4.75 & 50 & \\
\hline & & 70 & 20 & 9.5 & 50 & \\
\hline \multirow{10}{*}{ v } & \multirow{2}{*}{$\begin{array}{c}V(0) \text { - Limestone } \\
(260-280)\end{array}$} & 76 & 10 & 6.0 & 50 & 100 \\
\hline & & 76 & 20 & 7.5 & 58 & 100 \\
\hline & \multirow{2}{*}{$\begin{array}{c}v(b) \text { - Limestone } \\
(340-20)\end{array}$} & 80 & 10 & 6.0 & 52 & 100 \\
\hline & & 80 & 20 & 7.5 & 61 & 100 \\
\hline & \multirow{2}{*}{$\begin{array}{c}V(c) \text { - Limestone } \\
(70-110)\end{array}$} & 80 & 10 & 6.0 & 52 & 100 \\
\hline & & 80 & 20 & 7.5 & 61 & 100 \\
\hline & \multirow{2}{*}{$\begin{array}{c}V(d) \text { - Limestone } \\
(150-180)\end{array}$} & 76 & 10 & 6.0 & 50 & 100 \\
\hline & & 76 & 20 & 7.5 & 58 & 100 \\
\hline & \multirow{2}{*}{$\begin{array}{c}\mathrm{V} \text { - Limestone - } \\
\text { Below } 230 \mathrm{~L}\end{array}$} & 80 & 10 & 4.0 & 60 & \\
\hline & & 80 & 20 & 5.0 & 67 & \\
\hline \multirow{2}{*}{ vi } & \multirow{2}{*}{ Kimberlite } & 80 & 10 & 6.0 & 52 & 100 \\
\hline & & 82 & 20 & 7.5 & 63 & 100 \\
\hline VII & $\begin{array}{c}\text { Red Head Rapids } \\
\text { Mudstone }\end{array}$ & 90 & 10 & 8.3 & 50 & \\
\hline VIII & $\begin{array}{c}\text { Churchill River } \\
\text { Mudstone }\end{array}$ & 90 & 10 & 10.0 & 45 & \\
\hline
\end{tabular}

Figure 4 Victor pit simplified geology and slope design sectors

These geologic (country rock and orebody) conditions have resulted in a stable pit with low risk of large-scale failure. Historically small rockfall has been common especially during freshet, rain events, or during freeze thaw cycles. Rockfalls tend to originate from areas where less competent rock is observed such as contact zones, blast-damaged crests, and the Red Head Rapids Formation (weaker mudstones and shales) in the lower part of Victor southwest or where more competent, blocky layers become overhung. Initial cuts in the clay overburden performed poorly resulting is some localised slumping, this was resolved in subsequent cutbacks by flattening the slope to 4:1. Slow erosion of the sporadic sand cells and overburden slopes has also been observed. Based on historical performance it is not expected that any new failure mechanisms will manifest during closure or post-closure. Figure 5 summarises the most significant falls of ground during the life-of-mine. As is evident from Figures 5 and 6 , Victor Mine has exhibited excellent slope performance. 


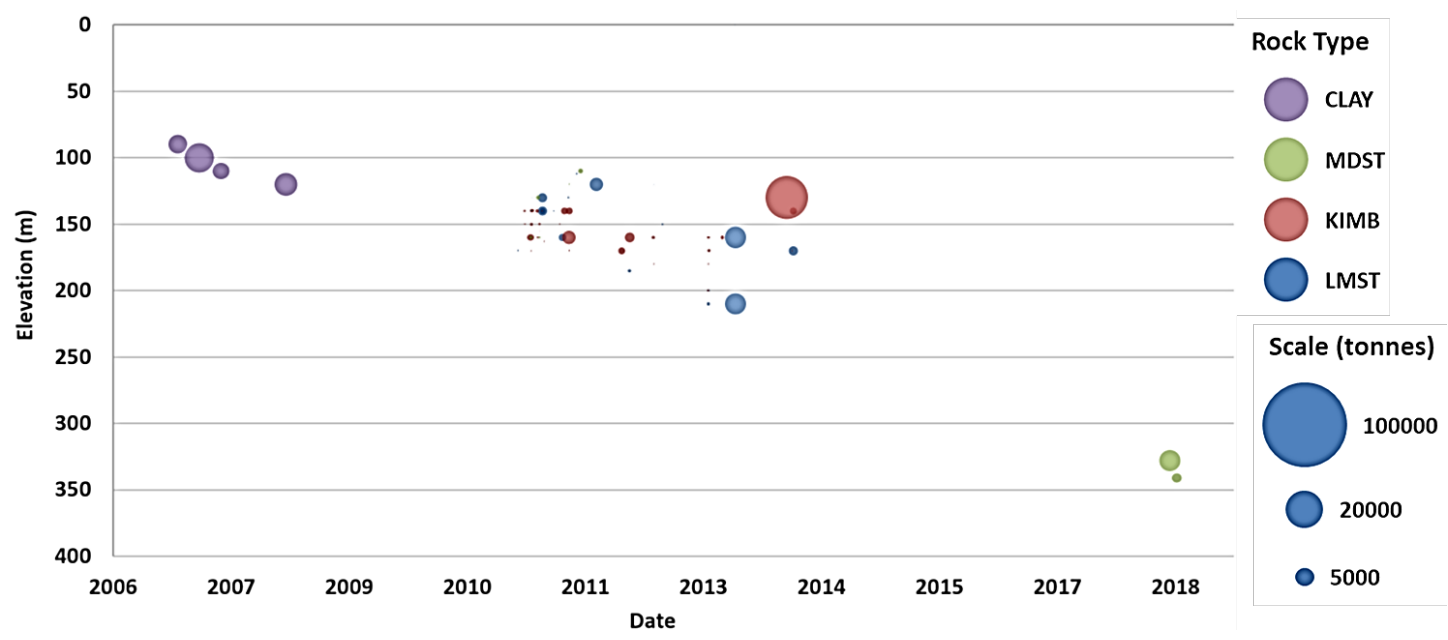

Figure 5 Summary of Victor Mine slope instabilities over life-of-mine

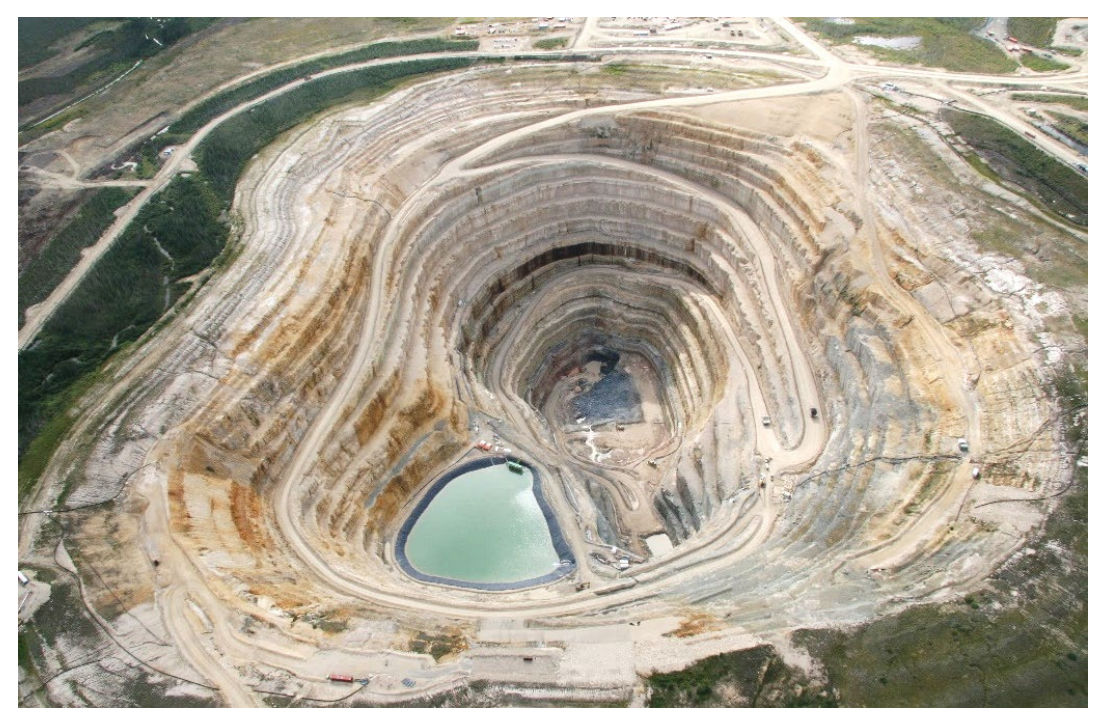

Figure 6 Photo showing overview of Victor Mine looking northeast. Note shallow overburden slopes and excellent limestone slope performance

\section{Voorspoed Mine: sub-sahara case history}

\subsection{Location and climate}

Voorspoed Mine is in the Free State Province of South Africa, about $30 \mathrm{~km}$ north of Kroonstad (where the workforce is based, Figure 7). The mine is accessed by all-weather road. De Beers acquired the mine in 1912 from the Voorspoed Diamond Mining Company who had difficulty mining the hard and competent kimberlite. DeBeers began production in 2008 and last ore was processed in December 2018; Voorspoed has produced occasional large and exotic coloured stones.

The climate is described as arid steppe, although generally dry the temperature variations are not as extreme as in the true deserts but are nevertheless large. The average temperature for the year $16^{\circ} \mathrm{C}$, with hot summers (January average $22^{\circ} \mathrm{C}$ ) and cool winters (June average $8^{\circ} \mathrm{C}$ ). Typically, $470 \mathrm{~mm}$ of rain is expected over the summer months with an average of 50 days of rain per year. Climate graph comparing Victor and Voorspoed mines is presented on Figure 3. 


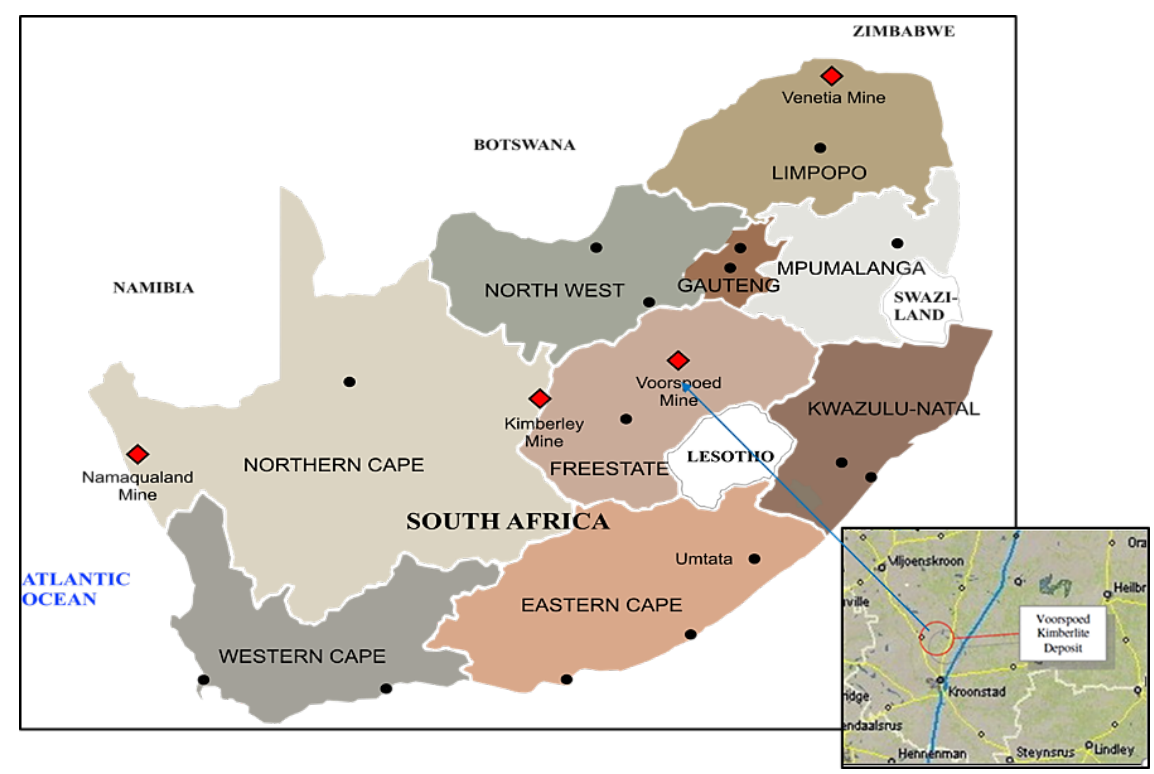

Figure 7 Voorspoed Mine locality map

\subsection{Geological setting}

The country rocks at Voorspoed are predominantly from the Permian period, and consist primarily of sedimentary rocks of the Volksrust (VO) Formation and the Vryheid (VR) Formation, within the Ecca Group and Karoo Supergroup. The VO includes; fine-grained, deep-water sediments that are dominated by a massive, but occasionally finely-laminated carbonaceous mudstone. The VR is an aerial and sub-aerial deltaic deposit that is either a fine-grained mudstone (VRM) or inter-bedded shale, sandstones and conglomerates (VRSSC). There is also a varved shale (VRVS) unit, lower in the sequence. The VR has been intruded by several dolerite sills of variable thickness. Figure 8(a) illustrates the Voorspoed pit lithological units. Most of the failures in the Voorspoed pit since the start of mining, occurred within these units and most failures were attributed to weak rock mass (Ekkerd et al. 2018).

The Voorspoed Kimberlite is one of the 11 pipes in the Kroonstad area. It comprises six different Volcanoclastic Kimberlite and Breccia sub-facies. The Kimberlite-Country Rock Breccia (KCBX), Country RockKimberlite Breccia (CKBX) and Kimberlite-Basalt Breccia (KBBX) are found along the pipe margins.

The geotechnical domains (ground control districts) at Voorspoed are largely determined by the main lithology, followed by bedding orientation and subdivision by major faults. The major lithologies can broadly be subdivided into two main categories:

- Soft rocks below 50 MPa (VO and VRM mudstones, VRSSC upper and VRVS), characterised by multiple bench slope instabilities.

- Hard rocks above $50 \mathrm{MPa}$ (Kimberlites, VRSSC Lower, Basalt, Dolerites), where rockfalls pose major hazards.

These ground control districts are further sub-divided based on the orientation of the pit slope and divided into pit sectors. Only rock masses with UCS 35th greater than $50 \mathrm{MPa}$ were considered for double benching, i.e. Basalt, Dolerite, CKBX and Kimberlite facies. Figure 8(b) shows the ground control districts and stack angles for different domains for Cut 3 Voorspoed pit.

Figure 9 illustrates the Voorspoed slope failure history and shows that most of the failures occur in the weak VO/VRM and CKBX materials. Slope performance has improved appreciably once mining extended below the strong VO/VRM; CKBX continued to present stability challenges to the ultimate pit depth. 


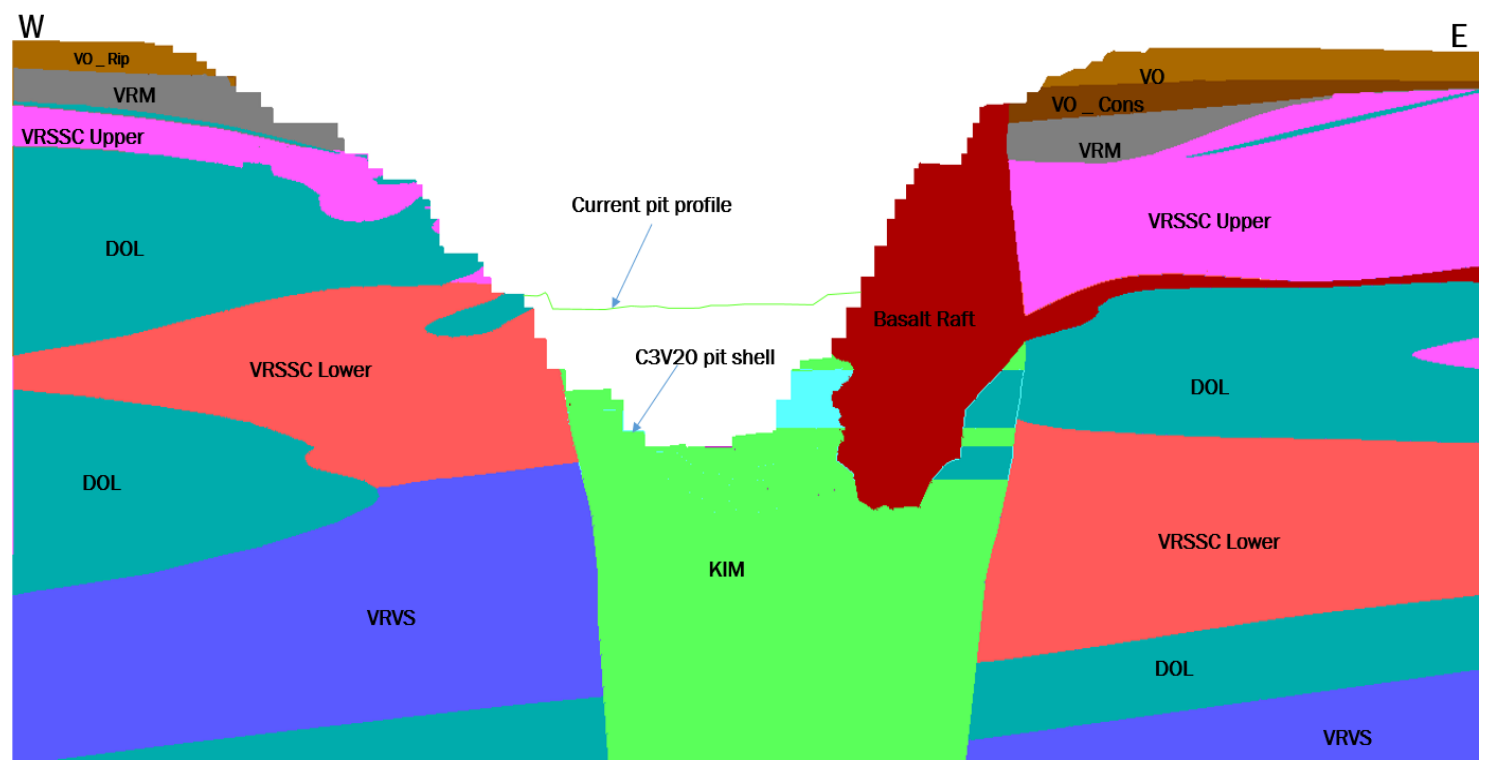

(a)

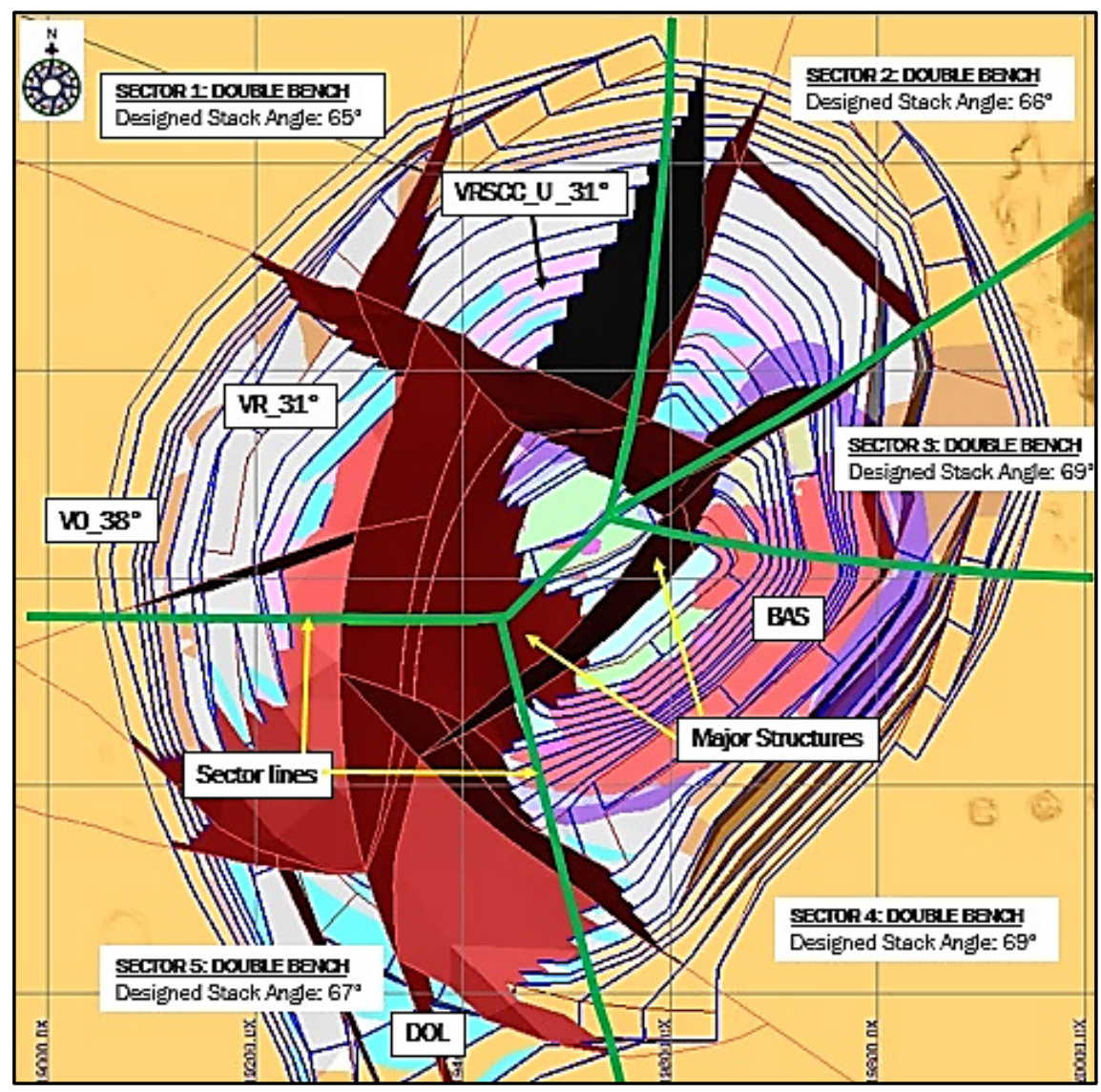

(b)

Figure 8 (a) Cross-section showing Voorspoed lithological units; (b) Plan view of Cut 3 design showing geotech domains and grouped stack angles for double benches and weak rock mass 


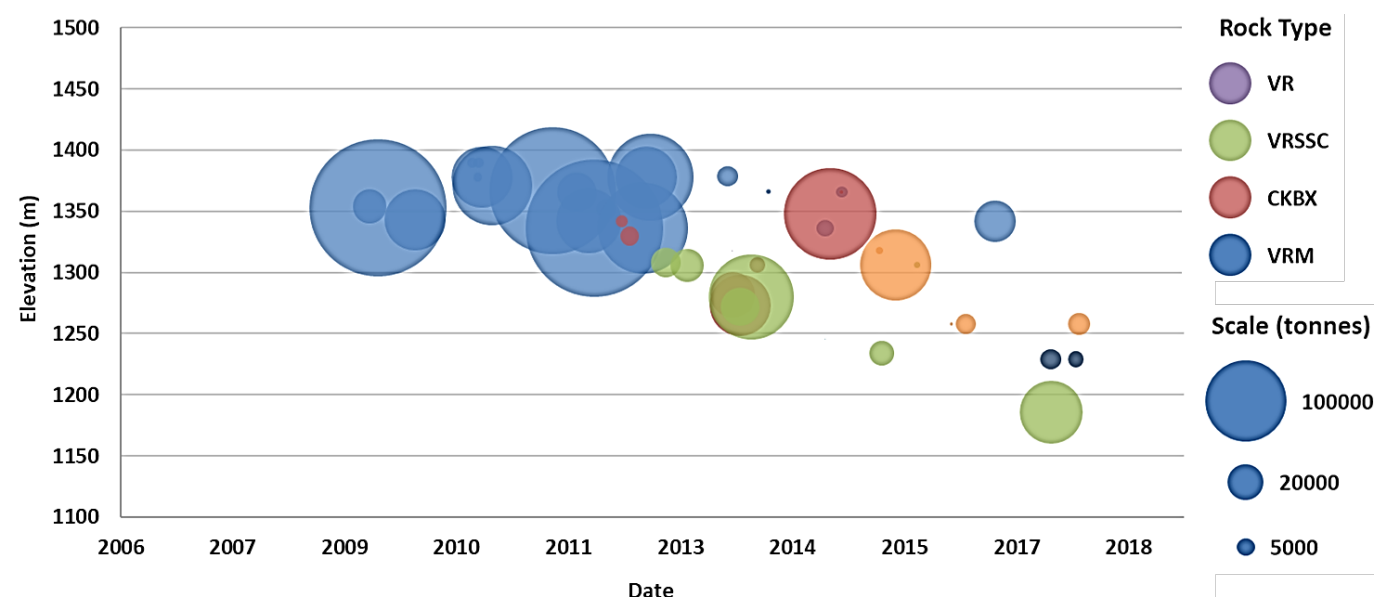

Figure 9 Summary of Voorspoed Mine slope instabilities over life-of-mine

\section{$4 \quad$ Closure objectives: long-term pit stability}

This evaluation is to quantify the long-term post-mining pit stability (not stability related safety issues in current mining operations), and to define the maximum extent of potential area of ground surrounding the pit that may be disturbed by the failure of the open pit walls over the long-term (i.e.: potentially unstable pit edge zone). This is used to define the minimum crest offset for closure bund or fence location. There is no infrastructure or important structures located near to either pit which could be at risk due to slope instability. The safe zone setback distance has been evaluated using empirical evidence based on historical slope instabilities and breakback angles, slope stability analysis and estimates of likely slope erosion.

\subsection{Pit crest breakback analysis}

\subsubsection{Empirical approach}

Victor Mine has essentially had no significant falls of ground so does not have any empirical performance data to draw on. However, Voorspoed has several failures that have been tracked over many years which have been used to predict an ultimate breakback angles (Figure 10). Four separate inter-ramp falls of ground were analysed (N11/N12, SW15, SSE1 and NE3/NE6 shown on Figure 11) which yielded breakback angles ranging from $13^{\circ}$ to $20^{\circ}$. Although local geology varies subtly between these sections, the SSE1 instability is considered the most pessimistic scenario since this represents the highest slope height of weak VOM/VR material and has historically been exposed to high phreatic surface conditions due to excessive surface runoff from the adjacent waste dump (Figure 10). The most conservative break back angle $\left(13^{\circ}\right)$ was used to determine the ultimate long-term pit back-break from the VOM/VR or VO/Dolerite contact.

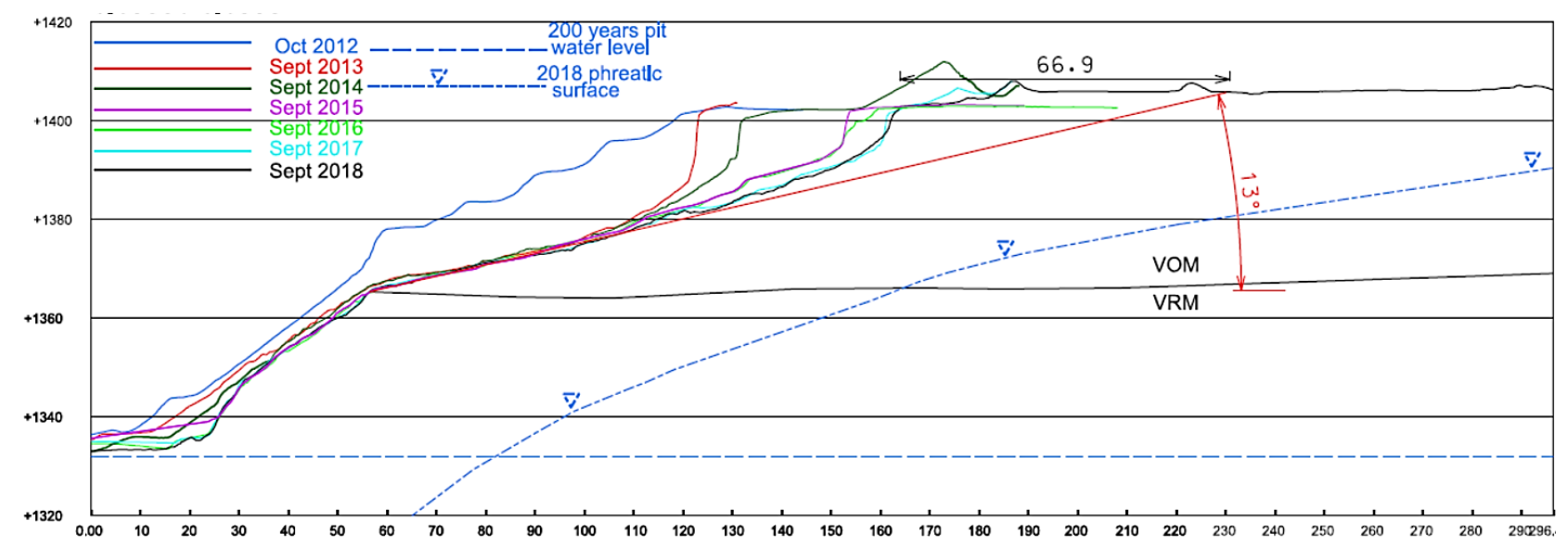

Figure 10 SSE1 failure angle of repose of $13^{\circ}$ and the ultimate long-term breakback distance of $67 \mathrm{~m}$ 


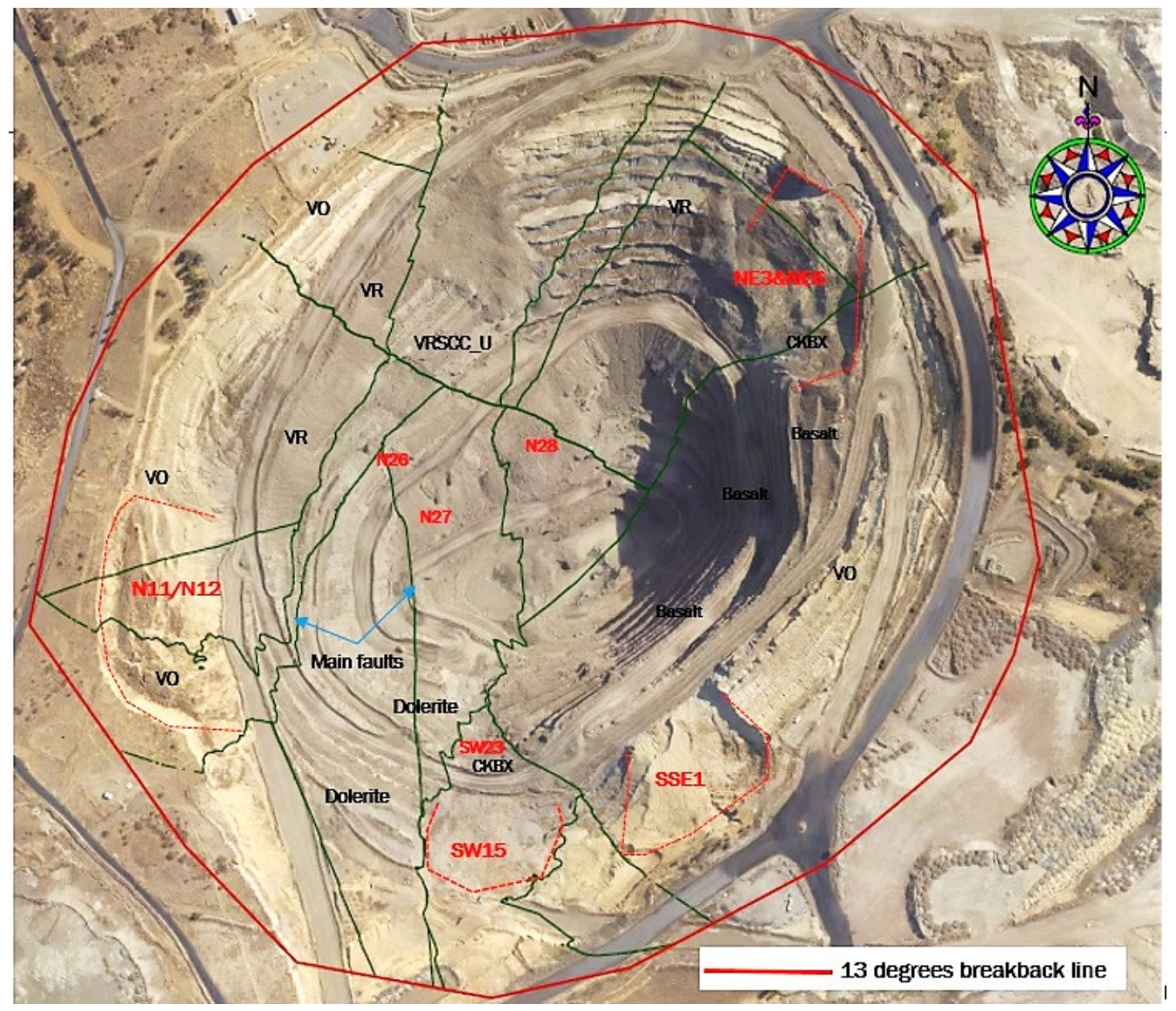

Figure 11 Plan view showing the pit back-break line around the Voorspoed pit

\subsubsection{Regulatory guidance}

Since Victor Mine did not have empirical backscarp failure data, regulatory guidance and other rules of thumb were trialled. Ontario Mines Regulations (2000) state that a closure berm shall be set back from the toe of the pit at least a distance equivalent to the pit depth (essentially a projection of $45^{\circ}$ from the pit bottom).

The Western Australian Department of Industry and Resource (1997) guideline also states that the zone of potential instability is defined by a wedge of material extending from the toe of the pit wall at $45^{\circ}$. This guideline also takes into consideration weathered rock conditions where the design angle should be further reduced to $25^{\circ}$ (Figure 12(a)). It is important to note that the use of these design criteria assumes that no major unfavourably oriented geological features are present within the pit walls, which could induce failure at flatter slope angles.

Due to the very gentle upper overburden slope mined 4:1 $\left(14^{\circ}\right)$ these guideline boundaries daylight within the pit (Figure 12(b)). The Western Australia guidance note recommends that where the overall angle of a pit wall is less than these design criteria, the bund wall is to be positioned at least $10 \mathrm{~m}$ away from the final pit wall crest. Similarly, for Voorspoed, due to the shallow upper slope profile these also daylighted within the pit. Due to previous instabilities on shallow near surface slopes, this was considered inadequate for closure requirements. Other approaches to define the safe setback were required. 


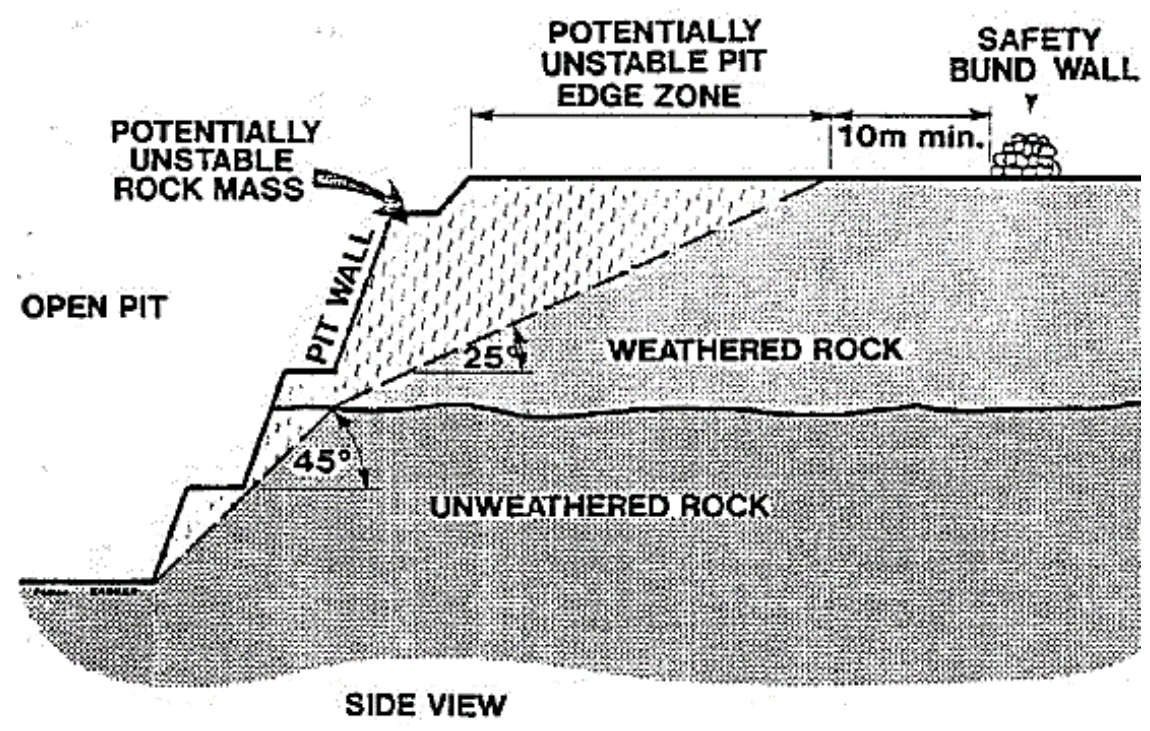

(a)

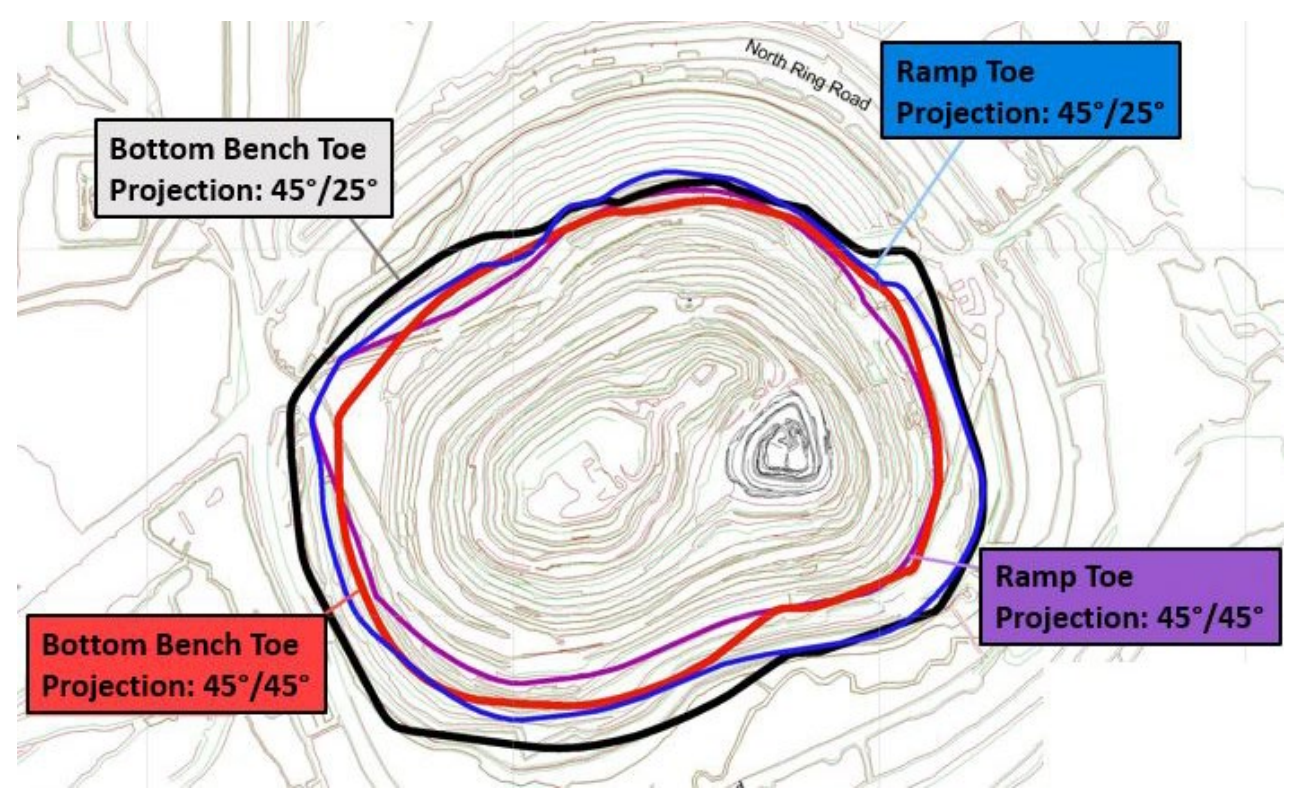

(b)

Figure 12 (a) Cross-section showing 'potentially unstable pit edge zone', after Department of Industry and Resource (1997); (b) Victor Mine 'guidelines' projection lines for location of safety berm

\subsection{Stability analysis}

Stability analyses were undertaken for both mine sites to determine the stability of the final pit void and quantify the Factor of Safety beyond the pit crest, and ultimately define the crest setback distance deemed acceptable for closure requirements (i.e. closure bund location).

But first the long-term design acceptance criteria (DAC) for closure needed to be agreed, the following section describes the approach adopted.

\subsubsection{Design acceptance criteria}

Generalised guidance for slope stability DAC are not yet defined for closure, this will be covered in a planned future Large Open Pit (LOP) research initiative. Typically closure DAC are based on a combination of designer's experience, perceptions of uncertainty and likely consequence of failure, and level of risk aversion of mine 
management. DAC guidelines for operational slope design (based on scale of instability and consequence of failure) are provided by Read \& Stacey (2009), adjustments for long design service life are typically done using engineering judgement. De Beers operational slope DAC are aligned with the LOP guidelines, and both mines were designed to meet these criteria. Due to the longevity of the design life +200 years the Group standard DAC was reviewed as they were are developed to provide design guidance for operating mines, not necessarily for long-term closure.

Carter 2014, provides a relevant commentary on expected service life from a longevity perspective. He states that with all natural systems there is an expectancy that stability will deteriorate with time, and this is implicit in the guidelines provided in Figure 13. The recommendations on service/design life from the perspective of crown pillars, consider the fact that real change from a longevity perspective will occur in rock quality, stress and water pressure conditions, irrespective of any change in crown geometry. Due to the potential risk for sudden catastrophic collapse associated with an often hidden (subterranean) void, the public risk associated with crown pillars is considered substantially greater than that for open pit closure and these guidelines are considered overly conservative for the open pit scenario.

\begin{tabular}{|c|c|c|c|c|c|c|c|c|}
\hline \multirow{2}{*}{$\begin{array}{c}\text { Probability } \\
\text { of Failure } \\
\%\end{array}$} & \multirow{2}{*}{$\begin{array}{l}\text { Minimum } \\
\text { Factor of } \\
\text { Safety }\end{array}$} & \multirow{2}{*}{$\begin{array}{l}\text { Maximum } \\
\text { Scaled } \\
\text { Span, } \\
\text { Cs }(=\text { Sc) }\end{array}$} & \multirow{2}{*}{$\begin{array}{l}\text { ESR } \\
\text { (Barton } \\
\text { et al. } \\
\text { 1974) }\end{array}$} & \multicolumn{5}{|c|}{ Design Guidelines for Pillar Acceptability/Serviceable Life of Crown Pillar } \\
\hline & & & & Expectancy & Years & $\begin{array}{l}\text { Public } \\
\text { Access }\end{array}$ & $\begin{array}{c}\text { Regulatory } \\
\text { position on } \\
\text { closure }\end{array}$ & $\begin{array}{c}\text { Operating } \\
\text { Surveillance } \\
\text { Required }\end{array}$ \\
\hline $50-100$ & $<1$ & $11.31 Q^{0.44}$ & $>5$ & Effectively zero & $<0.5$ & Forbidden & $\begin{array}{l}\text { Totally } \\
\text { unacceptable }\end{array}$ & Ineffective \\
\hline $20-50$ & 1.0 & $3.58 Q^{0.44}$ & 3 & $\begin{array}{l}\text { Very, very short-term } \\
\text { (temporary mining purposes } \\
\text { only ; unacceptable risk of } \\
\text { failure for temporary civil } \\
\text { tumnel portals }\end{array}$ & 1.0 & $\begin{array}{l}\text { Forcibly } \\
\text { Prevented }\end{array}$ & $\begin{array}{l}\text { Not } \\
\text { acceptable }\end{array}$ & $\begin{array}{l}\text { Continuous } \\
\text { sophisticated } \\
\text { monitoring }\end{array}$ \\
\hline $10-20$ & 1.2 & $2.74 Q^{0.44}$ & 1.6 & $\begin{array}{l}\text { Very short-term (quasi- } \\
\text { temporary stope crowns; } \\
\text { undesirable risk of failure for } \\
\text { temporary civil works) }\end{array}$ & $2-5$ & $\begin{array}{l}\text { Actively } \\
\text { prevented }\end{array}$ & $\begin{array}{l}\text { High level of } \\
\text { concern }\end{array}$ & $\begin{array}{l}\text { Continuous } \\
\text { monitoring } \\
\text { with } \\
\text { instruments }\end{array}$ \\
\hline $5-10$ & 1.5 & $2.33 Q^{0.44}$ & 1.4 & $\begin{array}{l}\text { Short-term (semi-temporary } \\
\text { crowns, e.g.under non- } \\
\text { sensitive mine infrastructure) }\end{array}$ & $5-10$ & Prevented & $\begin{array}{l}\text { Moderate } \\
\text { level of } \\
\text { concern }\end{array}$ & $\begin{array}{l}\text { Continuous } \\
\text { simple } \\
\text { monitoring }\end{array}$ \\
\hline $1.5-5$ & 1.8 & $1.84 Q^{0.44}$ & 1.3 & $\begin{array}{l}\text { Medium-term (semi- } \\
\text { permanent crowns, possibly } \\
\text { under structures) }\end{array}$ & $15-20$ & Discouraged & $\begin{array}{l}\text { Low to } \\
\text { moderate } \\
\text { level of } \\
\text { concern }\end{array}$ & $\begin{array}{l}\text { Conscious } \\
\text { superficial } \\
\text { monitoring }\end{array}$ \\
\hline $0.5-1.5$ & 2 & $1.12 Q^{0.44}$ & 1 & $\begin{array}{l}\text { Long-term (quasi-permanent } \\
\text { crowns, civil portals, near- } \\
\text { surface sewer tunnels) }\end{array}$ & $50-100$ & Allowed & $\begin{array}{l}\text { Of limited } \\
\text { concern }\end{array}$ & $\begin{array}{l}\text { Incidental } \\
\text { superficial } \\
\text { monitoring }\end{array}$ \\
\hline$<0.5$ & $\gg 2$ & $0.00 Q^{0.4 t}$ & 0.8 & $\begin{array}{l}\text { Very long-term (permanent } \\
\text { crowns over civil turnels) }\end{array}$ & $>100$ & Free & of no concern & $\begin{array}{l}\text { None } \\
\text { required }\end{array}$ \\
\hline
\end{tabular}

Figure 13 Acceptable Risk Exposure Guidelines: comparative significance of crown pillar failure (Carter 2014)

More recently, consideration for confidence in input models and design parameters along with the scale of instability and consequence of failure; using these factors to adjust the DAC in accordance with the risk. Hawley \& Cunning (2017) document an example of this approach for waste dump design. Adams (2015) provides a risk matrix framework for developing slope stability DAC based on i) confidence in design inputs, ii) failure consequence level, and iii) design service life. Design input confidence levels are somewhat subjectively rated high, medium or low.

The Victor and Voorspoed design input models and slope performance are ranked and presented in Table 2. Victor Mine confidence ratings are typically high while Voorspoed mostly are rated 'low-moderate'. Due to the historical poor slope performance, an additional level of conservatism has been applied in collectively adopting a 'low' confidence level for Voorspoed. An unintended benefit from the relatively poor slope performance has been the opportunity for multiple back analyses to refine material properties. 
For design purposes, corporate approved consequence and risk tables were used, however for the purposes of this paper the example consequence table provided by Adams are used to illustrate the process followed. Adams' example consequence and Factor of Safety (FoS)-Probability of Failure (PoF) (FoS-PoF) selection matrix are reproduced in Figures 14 and 15.

Table 2 Summary of Victor and Voorspoed design input model confidence and historical slope performance

\begin{tabular}{|c|c|c|c|c|c|}
\hline \multicolumn{2}{|l|}{ Input Model } & $\begin{array}{l}\text { Victor Mine } \\
\text { Complexity }\end{array}$ & Confidence & $\begin{array}{l}\text { Voorspoed Mine } \\
\text { Complexity }\end{array}$ & Confidence \\
\hline \multicolumn{2}{|l|}{ Geotechnical } & Low & Moderate & Low & Moderate \\
\hline \multicolumn{2}{|l|}{ Geological } & Low - moderate & High & Low - moderate & Low - moderate \\
\hline \multicolumn{2}{|c|}{ Hydrogeological } & Low & High & Low & Low - moderate \\
\hline \multicolumn{2}{|l|}{ Structural } & Low & High & Low - moderate & Low - moderate \\
\hline \multirow{4}{*}{$\begin{array}{l}\text { Historical } \\
\text { slope } \\
\text { performance }\end{array}$} & Bench & \multicolumn{2}{|c|}{$\begin{array}{l}\text { Rockfall risk associated with } \\
\text { freshet }\end{array}$} & \multicolumn{2}{|l|}{ Poor - fair } \\
\hline & Multi-bench & \multicolumn{2}{|l|}{ Excellent } & \multicolumn{2}{|c|}{ Several multi-bench Instabilities } \\
\hline & Inter-ramp & \multicolumn{2}{|l|}{ Excellent } & \multicolumn{2}{|c|}{ Some inter-Ramp Instabilities } \\
\hline & Overall & \multicolumn{2}{|l|}{ Excellent } & \multicolumn{2}{|c|}{ Good } \\
\hline
\end{tabular}

\begin{tabular}{|c|c|c|c|c|c|}
\hline \multirow{2}{*}{$\begin{array}{l}\text { Impact } \\
\text { Category }\end{array}$} & \multicolumn{5}{|c|}{ Consequence Level } \\
\hline & Insignificant & Minor & Moderate & Major & Catastrophic \\
\hline $\begin{array}{l}\text { Health \& } \\
\text { Safety }\end{array}$ & $\begin{array}{l}\text { First aid injury } \\
\text { (e.g. very slow } \\
\text { landslide with } \\
\text { minimal safety risk) }\end{array}$ & $\begin{array}{l}\text { Medical aid } \\
\text { injury } \\
\text { (e.g. slow to moder } \\
\text { be exposed to seo }\end{array}$ & $\begin{array}{l}\text { Lost Time Injury } \\
\text { (LTI) } \\
\text { te pit-slope moveme } \\
\text { ondary rockfall or ten }\end{array}$ & $\begin{array}{l}\text { Permanent } \\
\text { impairment } \\
\text { where people may } \\
\text { on crack hazards) }\end{array}$ & $\begin{array}{l}\text { Fatality } \\
\text { (e.g. any rapid } \\
\text { failure with people } \\
\text { exposed) }\end{array}$ \\
\hline Environment & $\begin{array}{l}\text { Contained } \\
\text { (e.g. wedge failure } \\
\text { contained on } \\
\text { bench, minimal } \\
\text { sediment to water) }\end{array}$ & $\begin{array}{l}\text { Localised impact } \\
\text { (e.g. sediment slug } \\
\text { from failure } \\
\text { contained by site } \\
\text { water controls) }\end{array}$ & $\begin{array}{l}\text { Impact within } \\
\text { mine only } \\
\text { (e.g. highwall } \\
\text { failure contained } \\
\text { within pit) }\end{array}$ & $\begin{array}{l}\text { Off-site impact } \\
\text { can be } \\
\text { remediated } \\
\text { (e.g. waste-rock } \\
\text { slide runout) }\end{array}$ & $\begin{array}{l}\text { Severe off-site } \\
\text { impact } \\
\text { (e.g. toxic tailings } \\
\text { release to external } \\
\text { waterway) }\end{array}$ \\
\hline Business & $\begin{array}{l}\text { No delay, cost < } \\
\$ 10 \mathrm{~K} \\
\text { (e.g. small failure } \\
\text { outside of work } \\
\text { area) }\end{array}$ & $\begin{array}{l}\text { Minor delay, } \\
\$ 10-\$ 100 \mathrm{~K} \\
\text { (e.g. inter ramp } \\
\text { slope failure } \\
\text { requires } \\
\text { stabilisation) }\end{array}$ & $\begin{array}{l}\text { Total loss } \$ 100 \mathrm{~K} \\
-\$ 5 \mathrm{M} \\
\text { (e.g. main access } \\
\text { ramp destroyed } \\
\text { causing delay and } \\
\text { re-planning) }\end{array}$ & $\begin{array}{l}\text { Total loss } \$ 5 \mathrm{M} \text { - } \\
\$ 100 \mathrm{M} \\
\text { (e.g. production pit } \\
\text { closed for } \\
\text { significant period, } \\
\text { ore sterilised) }\end{array}$ & $\begin{array}{l}\text { Total financial } \\
\text { loss > \$100M } \\
\text { (e.g. failure large } \\
\text { enough to close } \\
\text { mine) }\end{array}$ \\
\hline
\end{tabular}

Figure 14 Example consequence table (Adams 2015)

Consequence ratings for both operations are essentially the same, with minor to moderate safety, financial, health, social and environmental outcomes. The principal consequence of not achieving the slope stability objectives are regulatory and reputational, these are rated as major.

Using the worst consequence rating for reputational and regulatory consequences the highest consequence category for > 10-year design life has been adopted with high and low level of design confidence for Victor and Voorspoed respectively. This results in minimum design FoS of 1.4 and 1.6 respectively, which was then adopted for closure stability requirements. 


\begin{tabular}{|c|c|c|c|c|c|c|c|c|c|c|}
\hline \multirow{2}{*}{\multicolumn{2}{|c|}{$\frac{\text { Consequence Level }^{1}}{\text { Level of Design Confidence }^{2}}$}} & \multicolumn{3}{|c|}{ Insignificant to Minor } & \multicolumn{3}{|c|}{ Moderate } & \multicolumn{3}{|c|}{ Major to Catastrophic } \\
\hline & & High & Med & Low & High & Med & Low & High & Med & Low \\
\hline \multirow{2}{*}{$\begin{array}{l}\text { Permanent } \\
\text { cut, fill or } \\
\text { natural slope } \\
\text { (Design Life } \\
>10 \text { years) }\end{array}$} & $\begin{array}{l}\text { Min FOS } \\
\text { Max POF }\end{array}$ & $\begin{array}{c}1.3 \\
20 \%\end{array}$ & $\begin{array}{c}1.3 \\
20 \%\end{array}$ & $\begin{array}{c}1.3 \\
20 \%\end{array}$ & $\begin{array}{c}1.3 \\
20 \%\end{array}$ & $\begin{array}{c}1.4 \\
10 \%\end{array}$ & $5 \%$ & $\begin{array}{c}1.4 \\
10 \%\end{array}$ & $\begin{array}{l}1.5 \\
5 \%\end{array}$ & $\begin{array}{l}1.6 \\
2 \%\end{array}$ \\
\hline & $\begin{array}{l}\text { Level of Risk } \\
\text { Management }\end{array}$ & \multicolumn{3}{|c|}{$\begin{array}{l}\text { No monitoring or } \\
\text { access restrictions }\end{array}$} & \multicolumn{3}{|c|}{$\begin{array}{l}\text { No monitoring or } \\
\text { access restrictions }\end{array}$} & \multicolumn{3}{|c|}{$\begin{array}{l}\text { Minimal monitoring for } \\
\text { defined timeframe, and/or } \\
\text { access restrictions }\end{array}$} \\
\hline \multirow{3}{*}{$\begin{array}{l}\text { Interim cut or } \\
\text { fill slope } \\
\text { (Design Life } \\
0.5-10 \text { years) }\end{array}$} & & 1.2 & & & 1.2 & & & 1.3 & 1.4 & 1.5 \\
\hline & & $30 \%$ & $25 \%$ & & $30 \%$ & & & $20 \%$ & $10 \%$ & $5 \%$ \\
\hline & $\begin{array}{l}\text { Level of Risk } \\
\text { Management }\end{array}$ & \multicolumn{3}{|c|}{$\begin{array}{l}\text { Basic GCMP including } \\
\text { periodic slope monitoring. } \\
\text { Access dependant of } \\
\text { safety risks }\end{array}$} & \multicolumn{3}{|c|}{$\begin{array}{l}\text { Comprehensive GCMP } \\
\text { including slope monitoring } \\
\text { and TARPS. Access } \\
\text { dependant of safety risks }\end{array}$} & \multicolumn{3}{|c|}{$\begin{array}{l}\text { Comprehensive GCMP } \\
\text { including slope monitoring } \\
\text { and TARPS. Access } \\
\text { dependant of safety risks }\end{array}$} \\
\hline \multirow{3}{*}{$\begin{array}{l}\text { Temporary cut } \\
\text { or fill slope } \\
\text { (Design Life } \\
<6 \text { months) }\end{array}$} & & 1.2 & 1.25 & 1.3 & 1.25 & 1.3 & 1.35 & 1.25 & 1.35 & 1.4 \\
\hline & OF & $30 \%$ & $25 \%$ & $20 \%$ & $25 \%$ & $20 \%$ & $15 \%$ & $25 \%$ & $15 \%$ & $10 \%$ \\
\hline & $\begin{array}{l}\text { Level of Risk } \\
\text { Management }\end{array}$ & \multicolumn{3}{|c|}{$\begin{array}{l}\text { Basic GCMP including } \\
\text { periodic slope monitoring. } \\
\text { Access dependant of } \\
\text { safety risks }\end{array}$} & \multicolumn{3}{|c|}{$\begin{array}{l}\text { Comprehensive GCMP } \\
\text { including slope monitoring } \\
\text { and TARPs. Access } \\
\text { dependant of safety risks }\end{array}$} & \multicolumn{3}{|c|}{$\begin{array}{c}\text { Comprehensive GCMP } \\
\text { including slope monitoring } \\
\text { and TARPs. No access to } \\
\text { slope. }\end{array}$} \\
\hline \multirow{3}{*}{$\begin{array}{l}\text { Excavation for } \\
\text { immediate } \\
\text { backfill } \\
\text { (Design Life } \\
\text { < several days) }\end{array}$} & & 1.05 & 1.1 & 1.15 & 1.1 & 1.15 & 1.2 & 1.15 & 1.2 & 1.25 \\
\hline & & $45 \%$ & $40 \%$ & $35 \%$ & $40 \%$ & $35 \%$ & $30 \%$ & $35 \%$ & $30 \%$ & $25 \%$ \\
\hline & $\begin{array}{l}\text { Level of Risk } \\
\text { Management }\end{array}$ & \multicolumn{3}{|c|}{$\begin{array}{l}\text { Detailed risk assessment } \\
\text { and robust operational } \\
\text { controls, including } \\
\text { continuous monitoring and } \\
\text { TARPs. No access to slope }\end{array}$} & \multicolumn{3}{|c|}{$\begin{array}{l}\text { Detailed risk assessment } \\
\text { and robust operational } \\
\text { controls, including } \\
\text { continuous monitoring and } \\
\text { TARPs. No access to slope }\end{array}$} & \multicolumn{3}{|c|}{$\begin{array}{l}\text { Detailed risk assessment } \\
\text { and robust operational } \\
\text { controls, including } \\
\text { continuous monitoring and } \\
\text { TARPs. No access to slope }\end{array}$} \\
\hline
\end{tabular}

Figure 15 Example Factor of Safety (FoS)-Probability of Failure (PoF) selection matrix (Adams 2015). ${ }^{1}$ Consequence level from business risk assessment, see Figure $14 .{ }^{2}$ Design confidence subjective rating. ${ }^{3}$ PoF calculated for the slope sector analyses, not the global PoF

\subsubsection{Stability results}

Stability checks were undertaken for both mines using RocScience SLIDE LE techniques to confirm stack and overall stability for various stages of pit lake development. For Victor Mine it was predicted that it would take 10 years for the pit lake to reach steady state, and as little as 2 years if augmented by reversing the dewatering pumps and augmenting inflow from the nearby Attawapiskat River. However, due to the high evaporation rates and low precipitation at Voorspoed it was predicted that steady state would only occur in more than 100 years' time. It was decided to engineer the local runoff catchment area to enhance runoff to the pit and improve pond development.

\subsubsection{Victor Mine}

Due to the equilibration of pore pressures between the slope and the pit lake, the highest risk of a pit wall failure is expected to be at the beginning of closure as the dewatering pumps are shut off and filling begins. This assumption was confirmed by the results of the five pit filling scenarios for Victor Mine. The scenarios modelled the watertable at increasing water levels from $0 \%$ to $100 \%$ full in $25 \%$ increments. At $0 \%$ there is no water in the pit however the lower pit walls are assumed to be saturated to $314 \mathrm{~L}$ (which is in alignment with late stage mining pore pressures verified by vibrating wire piezometers (VWPs)). At $100 \%$ the water level is set to the $95 \mathrm{~m}$ bench, the pre-mining water level ( 85 masl).

The orientation of the three cross-sections was selected to intersect the deepest part of Victor southwest as well as intersect VWP installed previously (Figure 16(a)). These VWPs were used to confirm pore pressure distributions. 
The results show that no large-scale instability is expected with factors of safety above 1.4 for almost all stages, and that the rising water further stabilises the pit walls due to increasing confining pressure and equalising the pore pressures that develop in the pit slopes (Table 3). This was one of the three key recommendations in the 2018 Victor Geotechnical Review Board Report supporting the rapid filling of the pit (de Graaf et al. 2018). FoS for Section 682 are below the long-term closure DAC until the pit lake is about 50\% full, but is still well above the operational DAC of 1.2.

Table 3 Summary of Victor Mine Factor of Safety (FoS) results for all cross-sections and pit lake filling scenarios

\begin{tabular}{lllllll}
\hline $\begin{array}{l}\text { Water level } \\
\text { (\% of pit filling) }\end{array}$ & $\begin{array}{l}\text { Water level } \\
\text { (bench elevation) }\end{array}$ & $\begin{array}{l}\text { FoS section } \\
\mathbf{6 8 1}\end{array}$ & $\begin{array}{l}\text { FoS section } \\
\mathbf{6 8 2}\end{array}$ & $\begin{array}{l}\text { FoS section } \\
\mathbf{6 8 3}\end{array}$ & Method & Surface type \\
\hline 0 & $370 \mathrm{~m}$ & 1.57 & 1.32 & 1.51 & GLE/MP & Non-circular \\
25 & $300 \mathrm{~m}$ & 1.53 & 1.37 & 1.46 & GLE/MP & Non-circular \\
50 & $230 \mathrm{~m}$ & 1.56 & 1.43 & 1.45 & GLE/MP & Non-circular \\
75 & $165 \mathrm{~m}$ & 1.64 & 1.53 & 1.62 & GLE/MP & Non-circular \\
100 & $95 \mathrm{~m}$ & 1.81 & 1.63 & 1.71 & GLE/MP & Non-circular \\
\hline
\end{tabular}

\subsubsection{Voorspoed Mine}

Seven analysis sections were chosen for Voorspoed (Figure 16(b)). Pit lake levels were predicted for 10, 20, 50, 100 and 200 year increments, and were used to determine crest breakback distances for FoS of 1.5, 1.75 and 2. Grid search with composite or non-circular slip surfaces was utilised as it was assumed that the overall slope failure would be controlled by weak internal rock mass with dolerite sills providing anisotropy. Results are illustrated on Figure 17(a) and 17(b).

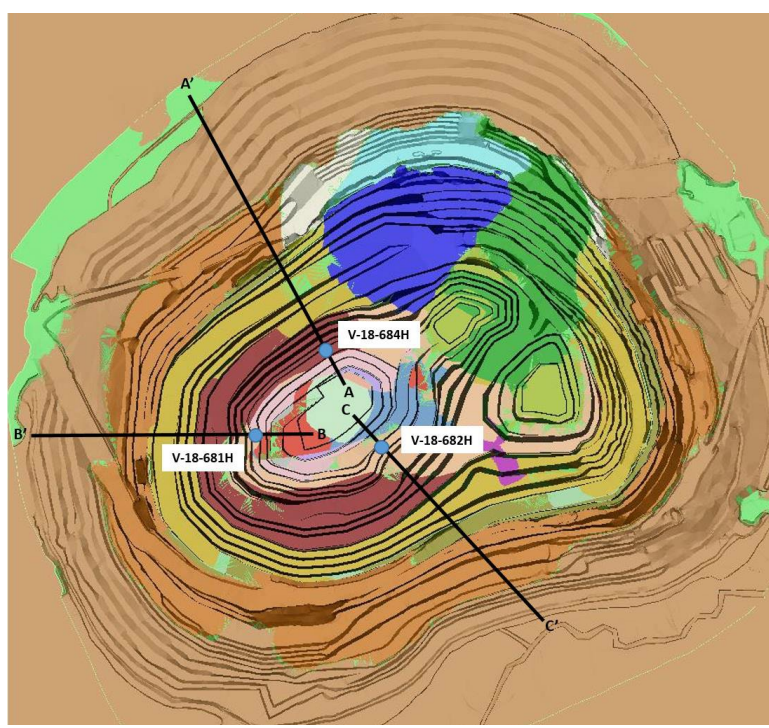

(a)

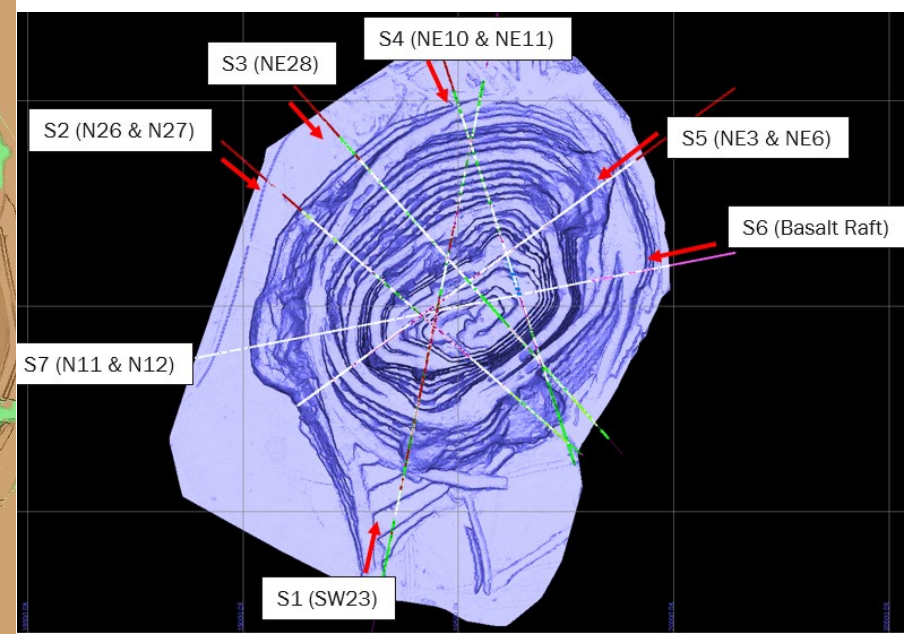

(b)

Figure 16 (a) Victor Mine cross-section locations; (b) Voorspoed Mine cross-sections used for SLIDE analyses. 


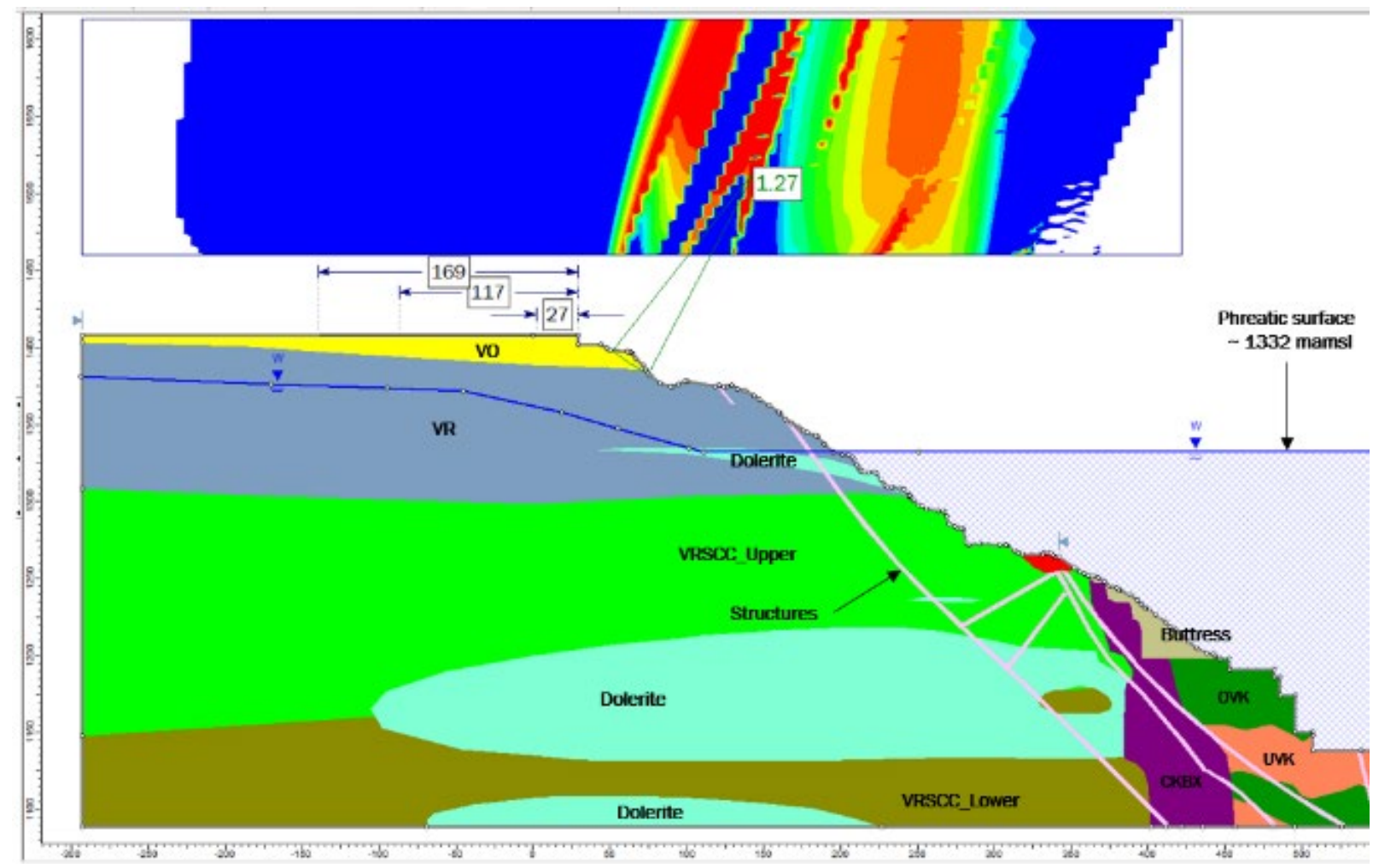

(a)

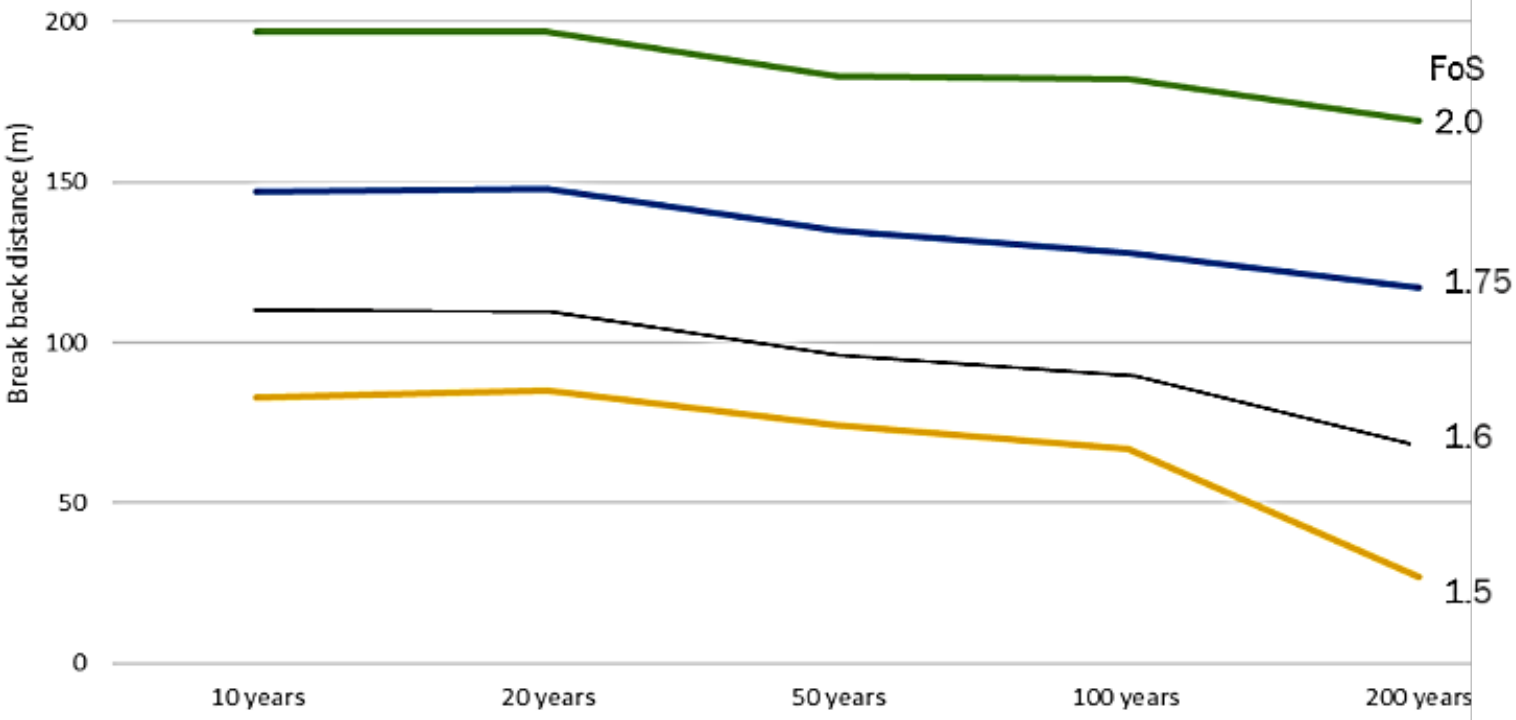

(b)

Figure 17 (a) Voorspoed Section 3 SLIDE model with phreatic surface at 1,332 mams; (b) Backbreak distance for Factor of Safety $\approx 1.5$ to 2.0 at different time steps (i.e. pit lake levels)

Limitations of the LE analysis technique are well documented, however this remains a valuable and cost-effective tool for evaluating stability and sensitivity to input parameters (slope geometry, shear strength parameters, pore pressure conditions), and is consequently widely used. Check analyses for both mines were undertaken using RS2 (FE) to confirm the validity of the failure mechanism and the relative stability, all be it 
using the shear strength reduction (SRF) approach. In both instances these results indicate reasonable congruency in both the stability results (5-11\% variation) and mode of instability between the LE and FE outcomes. This provides confidence in the SLIDE analysis results.

\subsection{Erosion and surface water management}

Early development of a stable pit lake level has several geotechnical benefits (improved overall slope stability and minimising slope area exposed to erosion). McCullough \& Schultze (2018), provide an interesting discussion on the risks and rewards of pit lakes. It is important that appropriate consideration and engineering design is applied to the surface water management plan. Water must not be allowed to pond within $200 \mathrm{~m}$ of the crest into the pit; importantly erosion controls must be engineered for the drainage works such that this does not promote gullying and erosion of the channels and/or pit slopes. If not engineered appropriately this could result in instability and surface impact beyond the predicted zone of influence.

Erosion due to wind or water can affect open pit stability either due to wave generation on the lake or by piping caused by pit inflow that has the potential to undercut the overburden slope. At Victor Mine piping through a sand layer was investigated, and the worst-case scenario predicted slope undercutting would resettle pushing the crest back $15 \mathrm{~m}$. Furthermore, erosion of the shoreline due to wind and wave action once the water level reaches equilibrium is possible, or more likely due to seasonal ice action, however since the upper slopes are gentle to very gentle it is postulated that erosion will be at equilibrium with deposition. Further, any material movements at these grades would not be expected to be progressive in nature due to limited mobility.

Since Voorspoed adopted a process of buttressing most of the weak ground falls of ground with either basalt or dolerite waste rock, the potentially erodible materials are largely protected. Figure 18(a) is a generalised cross-section showing pit lake levels for the western wall of the pit and potential interaction with geology and previous instabilities. The water levels after 10 and 20 years intersect previously buttressed areas, and after 50 years submerges all weak rocks therefore erosion is expected to be insignificant in these areas. Localised instability associated with the N26 instability will have negligible impact on overall slope performance. To mitigate erosion a surface water management plan has been developed (Figure 18(b)) to preferentially divert flows over the competent units (basalt and dolerite) rather than over the sedimentary rocks (which are susceptible to erosion).

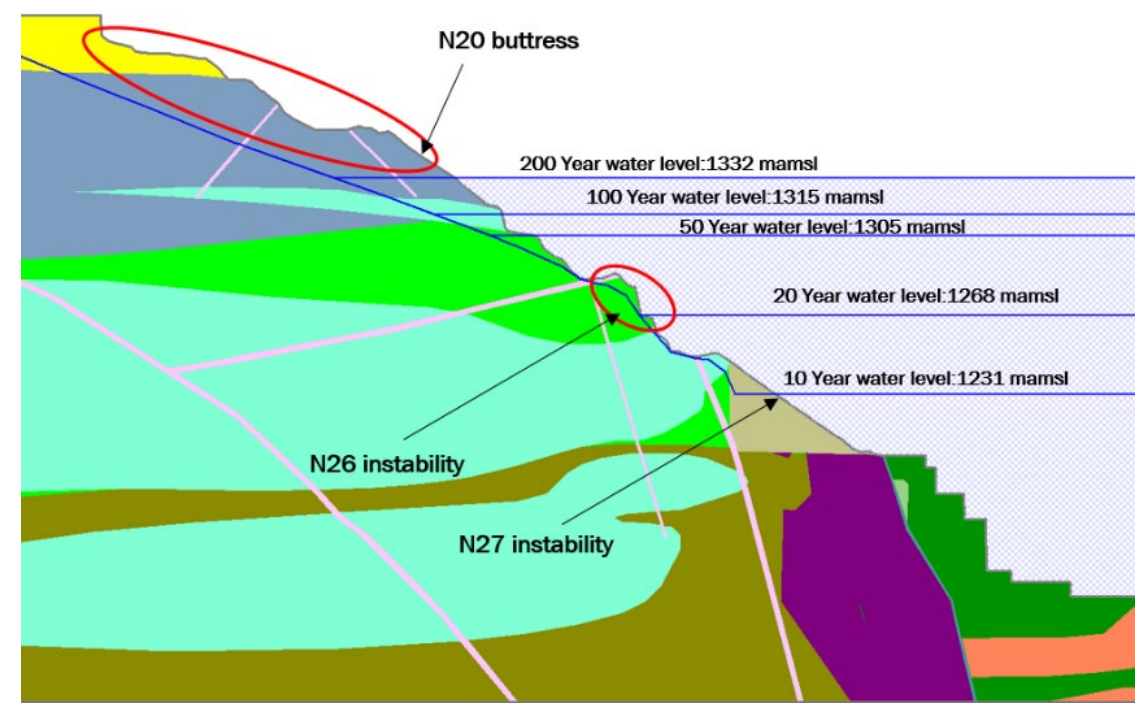

(a) 


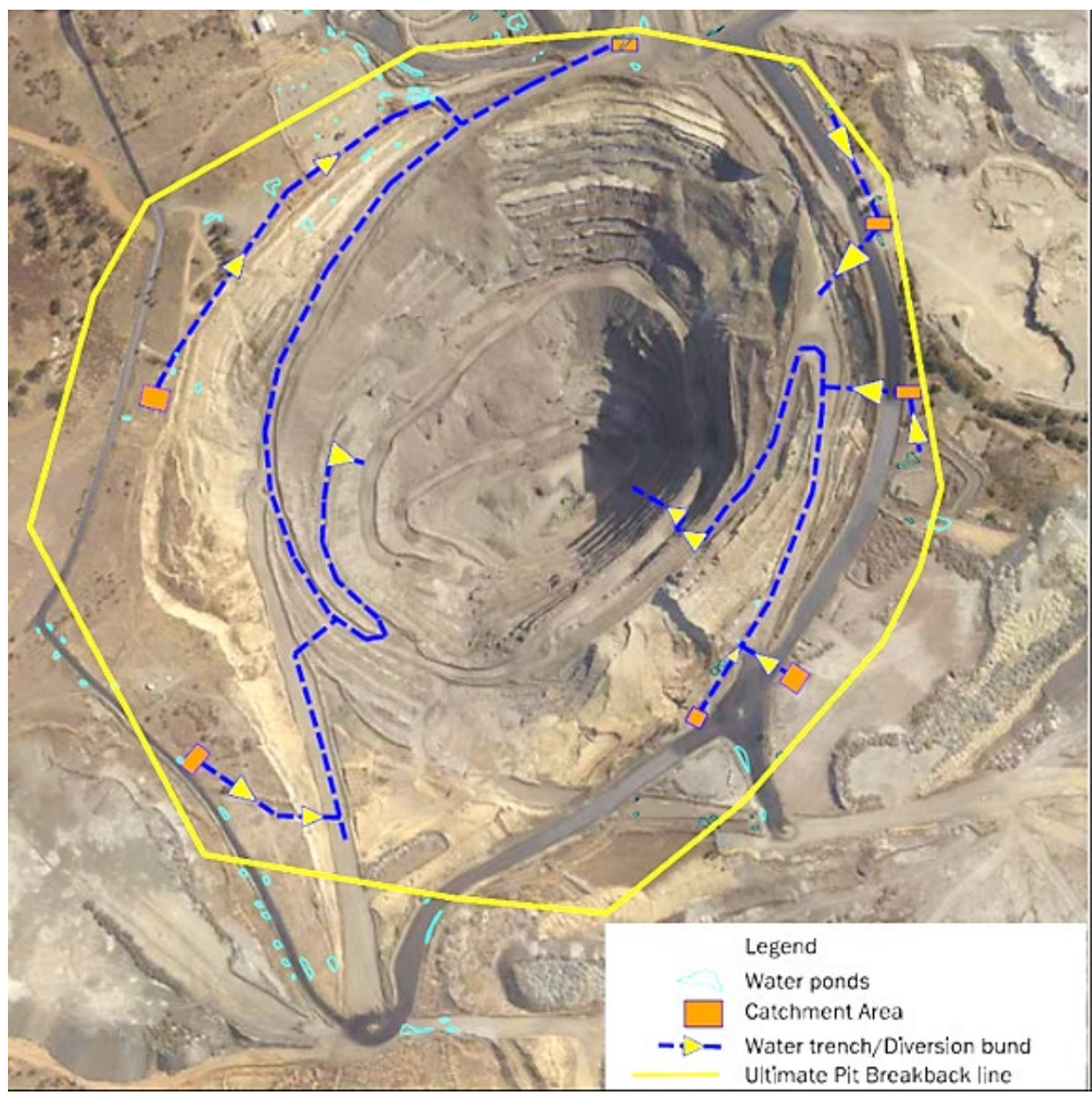

(b)

Figure 18 (a) Cross-section illustrating pit lake levels and geology intercepts; (b) Voorspoed surface water management plan to mitigate erosion

\subsection{Recommended pit perimeter setback distance}

Due to Victor Mine's extremely remote location and since the pit lake will ultimately flood to the pit crest the risk due to inadvertent entry is low. Victor is dependent on an ice road for access, therefore the consequences are significant for getting it wrong and implementing remedial actions. Stability analyses indicate very favourable conditions. For practical purposes, it is recommended that the ring road is adopted as the perimeter berm. FoS at this location is substantially higher than 1.4 for all modes and scales of instability, and the ring road can easily be modified to achieve the regulatory $2 \mathrm{~m}$ high perimeter berm.

Since Voorspoed is surrounded by farms, this will require a combination of berm (surface water management) and fence (enforced exclusion zone). The exclusion zone has been determined by the greater of the FoS 1.6 and $13^{\circ}$ breakback lines (Figure 19). 


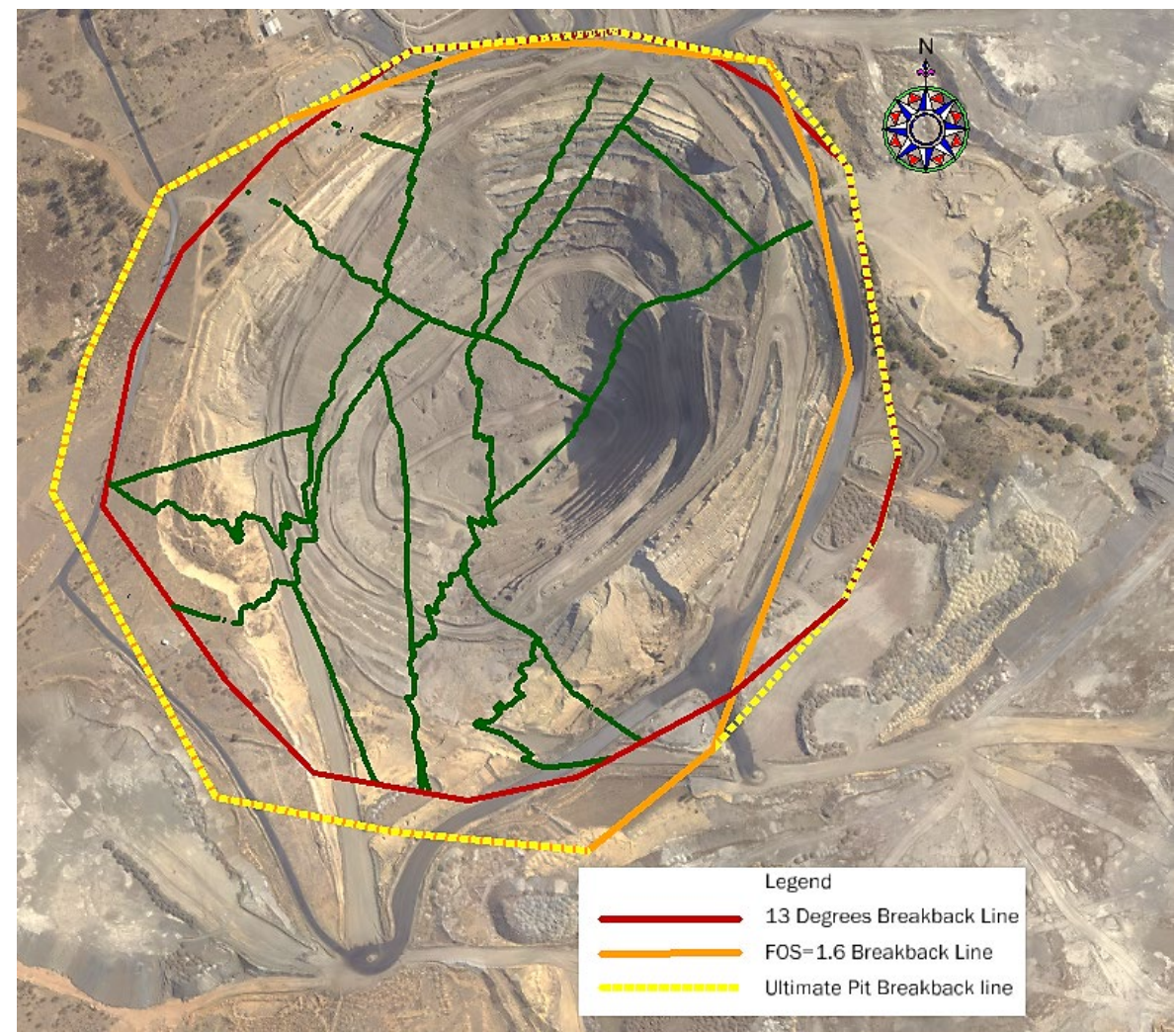

Figure 19 Ultimate pit exclusion zone defined by more conservative of the empirical $13^{\circ}$ breakback angle and Factor of Safety $=1.6 \mathrm{LE}$ breakback line

\section{$5 \quad$ Geotechnical risk assessment}

Based on orebody knowledge credible modes of instability have been evaluated and risk assessed; these outcomes have been used to develop hazard maps and long-term monitoring plans.

\subsection{Hazard maps}

Hazard maps were developed for each mine using the operational hazard maps as a starting point and augmenting these by reviewing the stability analysis outcomes for various stages of closure (i.e.: pit lake elevations) (Desjardins 2018; Tsheko et al. 2019). This proved invaluable to communicate the changing risk profile and hazard areas to management and the workforce during closure. Hazard maps for the initial and final Victor phases of closure are shown on Figure 20, and Figure 21 shows the final stage for Voorspoed.

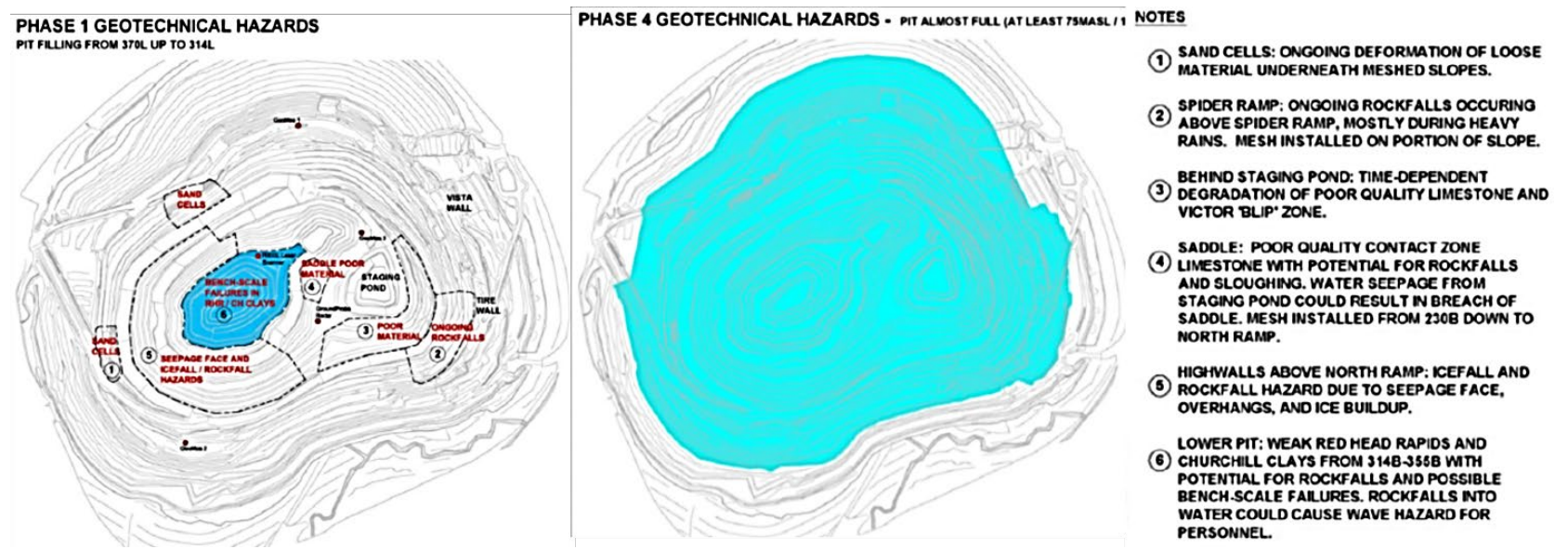

Figure 20 Evolving Victor Mine Hazard maps in response to pit lake changes (initial and last stages) 


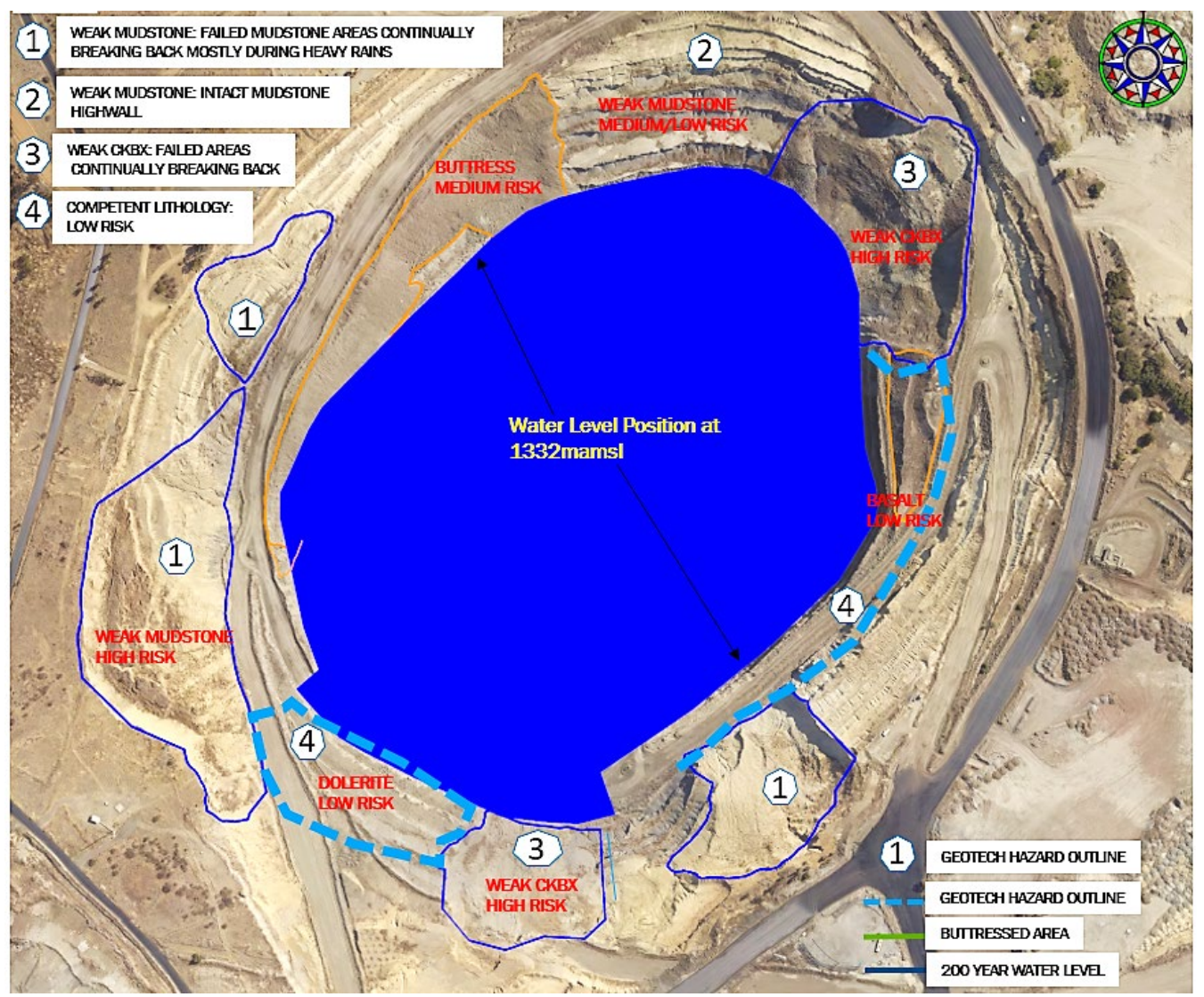

Figure 21 Voorspoed geotechnical hazard map for the ultimate pit lake

\subsection{Risk assessments and TARPs}

Formal risk workshops with relevant stakeholders were held to review potential geotechnical risks associated with closure. The greatest safety risk is associated with material falling from the walls. This is due to the danger posed to personnel safety in the pit during the active closure phase.

The risk assessment focused on two time periods:

1. Initial (active) closure period (i.e. time during active remediation works, personnel and equipment potentially operating within the pit and ring road), and

2. Long-term closure (i.e. personnel and equipment not permitted within the long-term break back zone).

The principal risk involves slope instability (or surface deformation) exceeds predicted breakback position. Primary controls include:

- Conservative design approach adopted (both empirical and LE stability) to define breakback position), i.e.: exclusion zone.

- Engineered control of surface water management plan (improve long-term stability):

$\circ$ preventing ponding and saturation within $200 \mathrm{~m}$ of the crest.

○ development of pit late as quickly as possible (improved stability).

- erosion management of inflow to mitigate excessive crest erosion.

- Long-term monitoring plan to detect early onset of potential instability and verify that these are in alignment with expected magnitude/zone of influence (e.g.: InSAR). 


\subsection{Long-term monitoring plan}

Victor Mine currently has four slope stability monitoring systems and methods: robotic surveying system (GeoMos), slope stability radar, laser scanner (RIEGL), and visual inspections. These monitoring systems provide early warning signs in case of slope failure.

A phased approach to monitoring is suggested as requirements change through the closure process. During the initial stages of closure, the existing geotechnical monitoring program will remain unchanged as there will be personnel in the pit. Because of the planned flooding of the pit, work start at the bottom of the pit and progress upwards. The recommended monitoring program takes this decommissioning sequence into account. Four phases are recommended to cover the monitoring needs from the day production ceases to when the mine is fully rehabilitated (Figure 22). The first three phases relate to active closure period.

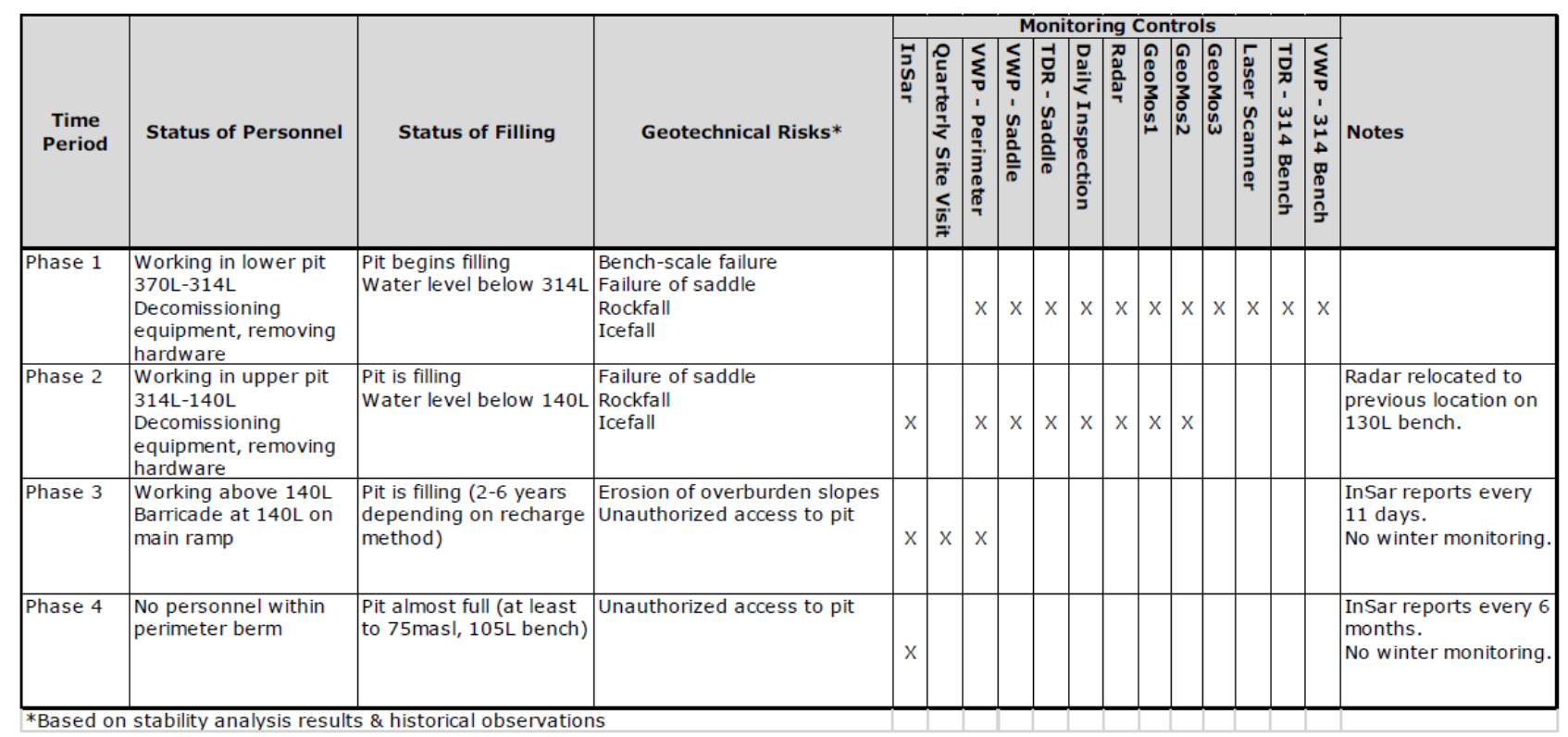

Figure 22 Victor Mine phased approach to pit monitoring through closure

Voorspoed Mine conducted the post-closure geotechnical risk assessment that identified the potential unwanted events to be managed:

- Surface deformation of full aerial extent of open pit walls and other areas to confirm that instability conforms to expected zone of influence.

- Groundwater and surface runoff i.e. the performance of drainage systems around the mine site is maintained to ensure runoff towards the pit lake.

The post-closure monitoring strategy at Voorspoed Mine comprises:

- Annual groundwater monitoring using piezometers.

- Annual visual inspection of the stormwater trenches two months before the wet season to give time for maintenance if necessary.

- Annual visual inspection of open pit crests for any signs of instability in exceedance of expected zone of deformation.

- Inspections to be undertaken by a Competent person or professional.

- InSAR is to be used for long-term deformation monitoring of open pit walls and surrounds. This well-established monitoring approach is extremely well suited to post-closure monitoring and holds several advantages over terrestrial monitoring approaches: 
- Fully remote automated system does not require any on the ground resources to perform monitoring.

- Full aerial coverage of the entire mine site to sub-millimetre accuracy is achieved (substantial improvement over terrestrial prism monitoring, which only provides data at discrete points and requires regular on the ground maintenance with ongoing dedicated local support).

- Standardised reporting comprising:

- Weekly change reports (an exception report flagging early identification of changed conditions).

- Annual detailed deformation report (including deformation vectors).

The management plans for both mines activities are aligned to TARPs reviewed by qualified professionals and will include annual reports submitted to the relevant authorities. Assurance has been provided by external reviewers as well as geotechnical review boards.

\section{Conclusion}

Victor Mine arguably presents a simpler closure scenario, with higher confidence input parameters, better historical slope performance, quick pit lake development and a very remote location. Voorspoed is more challenging with lower confidence input models (somewhat offset by extensive empirical break back data and back-analysis of instabilities), poor slope performance and slow pit lake development and is surrounded by farm land. Although the environmental and hydrogeological conditions for Victor and Voorspoed mines are very different, a similar approach to developing geotechnical closure plans has been possible. The methodical approach for evaluation appropriate closure DAC based on i) confidence in design inputs, ii) failure consequence, and iii) design service life has provided a rational approach to reconciling the differences between these operations and developing appropriate closure plans (and implementation risk management) to ensure that closure of the pit proceeds safely and efficiently while satisfying the regulatory requirements.

\section{Acknowledgement}

The contributions of colleagues and consultants in developing the respective geotechnical closure management systems are acknowledged. With special mention to Geoff Beale for constructive comments in reviewing this paper. Furthermore, permission from De Beers and Anglo American management, to publish this work is also gratefully acknowledged.

\section{Disclaimer}

All opinions and conclusions drawn in this paper are those of the authors alone and it should not be assumed that any views expressed herein are also necessarily those of De Beers or Anglo American.

\section{References}

Adams, BM 2015, 'Slope Stability Acceptance Criteria for Opencast Mine Design', Proceedings of the 12th Australia New Zealand Conference on Geomechanics, Wellington.

Agricola, G 1556, De Re Metallica [Subject Metals], Dover Publications, New York, pp. 638.

Brown, ET \& Ferguson, GA 1979, 'Progressive Hangingwall Caving at Gath's Mine, Rhodesia', Transactions of the Institution of Mining and Metallurgy, vol. 88, pp. A92-105.

Carter, TG 1992, 'A New Approach to Surface Crown Pillar Design', Proceedings of the 16th Canadian Rock Mechanics Symposium, Canadian Rock Mechanics Association, Sudbury, pp. 75-83.

Carter, TG 2014, 'Guidelines for use of the Scaled Span Method for Surface Crown Pillar Stability Assessment', Proceedings of the 1st International Conference on Applied Empirical Design Methods in Mining, International Society for Rock Mechanics and Rock Engineering, Lima.

Carter, TG \& Miller, RJ 1995, 'Crown Pillar Risk Assessment - Cost Effective Measures for Mine Closure Remediation Planning', Transactions of the Institution of Mining and Metallurgy, vol. 104, pp. A41-A57.

de Graaf, P, Johnson, R \& Beale, G 2018, Victor Mine - 2018 Geotechnical Review Board Report, unpublished. 
Department of Industry and Resources 1997, Safety Bund Walls Around Abandoned Open Pit Mines Guideline, Government of Western Australia.

Desjardins, M 2018, Victor Mine De Beers Canada Inc. Geotechnical Closure Report, Internal Report, unpublished.

Ekkerd, J, Tsheko, P \& Ruest, M 2018, 'Voorspoed Mine, South Africa: Open Pit Diamond Mining in Weak Mudrock', in D Martin \& P Stacey (eds), Guidelines for open pit slope design in weak rocks, CSIRO Publishing, Clayton.

Flores, G \& Karzulovic, A 2002, Geotechnical Guidelines for a Transition from Open Pit to Underground Mining, Benchmarking Report for ICSII, Task 4.

Hawley, PM \& Cunning, J 2017, Guidelines for Mine Waste Dump and Stockpile Design. CSIRO Publishing, Collingwood.

Hoek, E 1974, 'Progressive Caving Induced by Mining an Inclined Orebody', Transactions of the Institution of Mining and Metallurgy, vol. 83, pp. A133-139.

Laubscher, DH 2000, Block Caving Manual, Prepared for International Caving Study, JKMRC and Itasca Consulting Group, Brisbane.

McCullough, CD \& Schultze, M 2018, Risks and Rewards of Pit Lakes, AusIMM Bulletin, December 2018, pp. 38-41.

National Coal Board 1975, Subsidence Engineers Handbook, 2nd edn, National Coal Board Mining Department, London.

Ontario Mines Regulation 2000, Regulation 240/00: Mine Development and Closure under Part VII of the Act.

Read, J \& Stacey, P 2009, Guidelines for Open Pit Slope Design, CSIRO Publishing, Collingwood.

Rougier, M, Ruest, M, Gauthier, P \& Horwitz, A 2015, 'The use of head drilling and of structural data from digital photography obtained by drone survey to justify slope steepening at Victor Diamond Mine', Proceedings of the 2015 International Symposium on Slope Stability in Open Pit Mining and Civil Engineering, The Southern African Institute of Mining and Metallurgy, Cape Town.

Sainsbury, B, Sainsbury, D \& Diana, C 2018, 'Back-analysis of PC1 cave propagation and subsidence behaviour at the Cadia East mine', in Y Potvin \& J Jakubec (eds), Proceedings of the Fourth International Symposium on Block and Sublevel Caving, Australian Centre for Geomechanics, Perth, pp. 167-178.

Salamon, MDG 1990, 'Mechanism of caving in longwall coal mining', in W Justrulid \& G Johnson (eds), Proceedings of the 31st U.S Symposium of Rock Mechanics, AA Balkema, Rotterdam.

Sharrock, G, Brunton, I \& Hebert, Y 2016, Design Charts: Subsidence Drawzones \& Caveability, Itasca Australia Confidential Report MMT-3 Sponsors.

Suchowerska Iwanec, AM, Carter, JP \& Hambleton, JP 2015, 'Geomechanics of subsidence above single and multi-seam coal mining', Journal of Rock Mechanics and Geotechnical Engineering, vol. 8, pp. 304313.

Tsheko, P, Muthelo, N \& Ratshitanga, M 2019, Voorspoed Mine Geotechnical Closure Report, Internal Report, unpublished.

van As, A, Davison, J \& Moss, I 2003, Subsidence Definitions for Block Caving Mines, Rio Tinto Technical report. 